\title{
Nursing the cure: A phonetic analysis of /ðə/ in South African English $^{1}$
}

\author{
Ian Bekker \\ School of Languages, North-West University, South Africa \\ E-mail: ian.bekker@nwu.ac.za
}

\begin{abstract}
This article is focused on providing the results of a partially impressionistic and partially acoustic phonetic analysis of the CURE vowel (i.e. / $/ 2 /$ as in cure, tour, sure) in South African English (SAfE) and, in particular, in the main first-language (L1) sociolect of this Southern Hemisphere variety, General SAfE. While the results confirm a high degree of variability in terms of the realisation of CURE in General SAfE, a couple of trends are identifiable. Firstly, while other non-rhotic varieties of English have undergone (or are undergoing) the Second FORCE Merger, whereby CURE merges with /o:/ (e.g. cure is pronounced [kjo:]), it would appear that the Second FORCE Merger has been arrested in the General SAfE of the recorded subjects (contra certain pronouncements in the extant literature and limited to some of the subjects and certain lexical items such as sure). Secondly, in word-internal position, CURE is inclined towards smoothing (and in some cases full monophthongisation) with the quality of the resultant vowel mostly dependent on the preceding consonant. After a palatal or palatoalveolar segment in word-internal position, there appears to be a partial merger with rounded, fronted SAfE NURSE (i.e. [ø:]), e.g. insurance is pronounced [In $\varnothing:$ Iəns]. In the case of nonpost-palatal, word-internal CURE, however, the smoothed realisations are further back in phonetic space. In word-final position, the trend is for CURE to be realised as canonical [və]. Generally, however, the presence in some cases of NURSE-like values in word-final position, particularly after palatal or palato-alveolar contexts (e.g. [mətøø:] for mature), as well as both the high degree of variability in the data overall and residual [o:]-realisations, point to processes of phonologisation and lexicalisation of both NURSE-like and other qualities, thus creating a large number of exceptions to the overall allophonic patterning in the data.
\end{abstract}

Keywords: South African English, CURE, NURSE, Second-FORCE Merger, phonetics

\footnotetext{
${ }^{1}$ Thanks go to two of my former students at Rhodes University, Judith Orpen and Lee-Anne Bruce, for conducting preliminary research on this topic, and particularly to Ms Bruce for collecting the data on which much of the current analysis is based. Thanks also go to the audiences at the Accents 2011 conference in Łódź, Poland, 1517 December 2011, the joint LSSA/SAALA/SAALT conference held at the University of Stellenbosch, 1-4 July 2013 and the Phonetics and Phonology of Sub-Saharan Languages conference held at the University of the Witwatersrand, 7-10 July 2013. This work is supported by the National Research Foundation (Grant no.: 78795). Any opinions, findings and conclusions or recommendations expressed in this material are those of the author; the NRF does not accept any liability in regard thereto. Thanks also go to two anonymous reviewers.
} 


\author{
He was an outlaw, that's for sure; \\ More of an outlaw, than you ever were.
}

Bob Dylan, Lenny Bruce is Dead

\title{
1. Introduction
}

For sure, Bob Dylan does not speak South African English (SAfE), but the quote above from his song Lenny Bruce is Dead (from the album Shot of Love) illustrates nicely the potential for homophony across tokens such as sure and were. In the case of American English, the reasons for such homophony are no doubt coloured by the presence of post-vocalic, "rhotic" $/ \mathrm{r} / 2$ but, regardless of this difference, a similar phenomenon appears to be evident in non-rhotic SAfE, where these very same two tokens could, I claim, also be used for rhyming purposes. The main aim of this article is thus to provide a more solid basis for the claim that SAfE displays at least a partial merger of the NURSE and CURE lexical sets 3 , or, more particularly, that such a partial merger is at least discoverable in the speech of a small sub-set of young, female General SAfE (GenSAfE) speakers, GenSAfE being the main sociolect of first language (L1) SAfE ${ }^{4}$. In section 2, some pertinent general information about SAfE is provided, while section 3 provides a review of the relevant literature relating to CURE and related phenomena in SAfE and other varieties of English; relevant topics include an overview of the Second FORCE Merger, the reported quality of SAfE CURE in the available literature as well as a review of other cases of the appearance, in English, of NURSE-like qualities in CURE. Section 4 will then provide an overview of the methodology employed in this research. Section 5 is divided into two subsections, the first reporting on the results of a phonetic analysis focused on CURE in postpalatal and post-palato-alveolar position, while the second is focused on a similar analysis of CURE in non-post-palatal position. Section 6 provides a more speculative discussion of the results and a conclusion.

\section{Brief background to South African English}

SAfE, one of the most recent extraterritorial varieties of English, was, in terms of the standard picture of the formation of this variety, formed during the course of the $19^{\text {th }}$ century, with its main features being determined by the input from the 1820 settlers into the Eastern Cape 5 (where they predominantly originated from southeast England and were less than middle-class) as well as the mid- $19^{\text {th }}$ century input into $\mathrm{Natal}^{6}$ (where immigrants originated from the north of England and were more middle class). The last great immigration of English speakers to South Africa was the result of the discovery of gold in Johannesburg in 1886, although the important role played by this period is, wrongly I believe, generally disregarded in the standard literature - see Bekker $(2012,2013)$ for more on this matter.

\footnotetext{
${ }^{2}$ While Dylan was certainly born in a rhotic area of the United States of America (Duluth, Minnesota), it is not always clear that, in his lyrics at least, he uses a rhotic accent.

${ }^{3}$ The terminology is that of Wells (1982).

${ }^{4}$ The focus of this paper is therefore on confirming that this phenomenon does indeed occur in SAfE. Further research will have to determine whether it also occurs (and to what extent) in other sub-groups of GenSAfE as well as other L1 and L2 varieties of SAfE.

${ }^{5}$ See Figure 1.

${ }^{6}$ See Figure 1 again: "Natal" is the rough equivalent of current-day KwaZulu-Natal.
} 


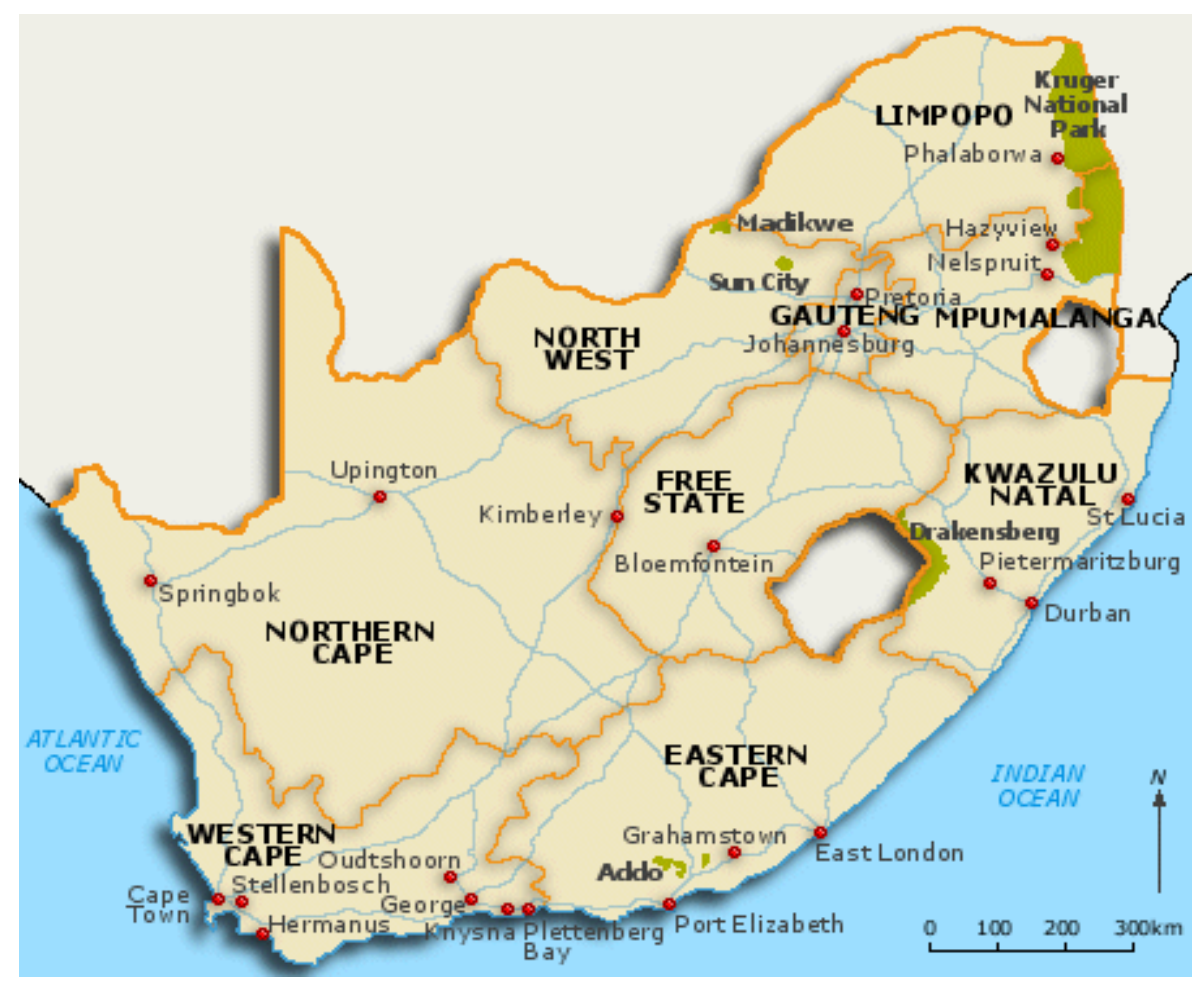

Figure 1. Map of South Africa

Nonetheless, the output of this formative period was a colonial English variety, characterised by a high degree of regional homogeneity, but with clearly discernable sociolects; these have come to be known as Cultivated SAfE (a Received Pronuniciation (RP)-like variety that is diminishing rapidly), GenSAfE (the local standard) and Broad SAfE (BrSAfE, arguably influenced by contact with Afrikaans). In this article, the focus is solely on GenSAfE as spoken traditionally by white individuals. There are other L1 and second-language (L2) varieties of English in South Africa, sadly still mainly correlating with Apartheid-era racial categories, although there is some evidence that, at least at middle-class level, a new non-racial variety of SAfE is being developed by the youth (Mesthrie 2010).

On a broad phonetic level, SAfE is generally non-rhotic, although very Broad speakers display variable rhoticity and a tapped /r/ (or [r]). SAfE has a clear-dark /l/ allophony, is characterised by a rather back, sometimes rounded BATH vowel and high TRAP and DRESS vowels. FLEECE and GOOSE are clearly monophthongal, and are not prone to the diphthongisation so prevalent in the other two main Southern Hemisphere varieties, namely Australian English (AusE) and New Zealand English (NZE). FACE is lowered and PRICE retracted in Broad varieties but not nearly so much in GenSAfE. SAfE is most famous for its so-called "KIN-PIN Split"; basically, word-initially, after /h/ and in a velar context, white South Africans use [I] (kick, it, hit), while in most other contexts a schwa is used (e.g. in bid or rim). Before dark /1/, there is even further retraction to [r] (e.g. in will). Of relevance to the following section is the fact that SAfE, like NZE, has a fronted, rounded NURSE vowel, namely [ $\ddot{\varnothing}$ :], not the unrounded [3:] quality found traditionally in RP. 


\section{CURE in SAfE and other English varieties}

\subsection{CURE in English}

The CURE lexical set is defined as "comprising those words whose citation form contains the stressed vowel /\%ə/ in conservative RP and the sequence / $\mathrm{r} /$ in GenAm [General American]" (Wells 1982:162). Phonetically, RP displays a diphthong moving from "a weakly rounded, somewhat close and back, [ $\mathrm{\sigma}$, moving towards a mid central quality" (Wells 1982:162). In versions of RP in which the First FORCE Merger has been completed (see footnote 7), the starting point can be somewhat more open and [oə]-like. In rhotic GenAm, "rather [u]-like qualities are occasionally encountered" (Wells 1982:163), e.g. in the case of / $/$ / before /r/.

A clarification is necessary of "conservative RP" in Wells' (1982) definition of RP CURE quoted above. This is because most RP speakers now pronounce CURE words with [0:], which is the vowel also found in THOUGHT, NORTH and FORCE7. This lack of distinction between the vowels in CURE and THOUGHT is the outcome of the so-called "Second FORCE Merger" (Wells 1982:236-237). The Second FORCE Merger is linked to another historical phenomenon, namely CURE Lowering. Thus, Wells (1982:56-57) confirms that in RP, the Second FORCE Merger is the result of a staged process beginning with the traditional [ひə] which is then pronounced [оә] (via a lowering of the nucleus), then [эə] and finally [0:] via glide-deletion, with the result that words such as sure become homophonous with shore and Shaw, "while poor falls in with pore, pour, and paw. Your and you're [...] become homophones of yore and yaw" (Wells 1982:237). The resultant merger has been observed in the speech of modern RP speakers, although partially and variably, as well as other varieties of English, particularly in the Southern Hemisphere, including Tristanian English, NZE, AusE and Falkland Islands English, though the vowel is often realised in these varieties as [o:] instead of the RP [0:] (Trudgill 2004a) ${ }^{8}$. Therefore, with respect to AusE, Wells (1982:600) provides the following analysis:

Cultivated pronunciation typically has [ซə] in poor/pøə/ and pure /pjoə/, [ซə] or [ত:] in boorish and security. But in words such as poor and pure broader accents have $/ \mathrm{s} /$, and the use of $/ \mathrm{s} / /$ for traditional / $/ \partial /$ is spreading, as in England, to educated accents as well.

More recently, Harrington, Cox and Evans (1997:174) conclude that AusE seems more advanced in terms of the Second FORCE Merger than Southern British English.

Likewise, Wells (1982:164) confirms that "everywhere in England the vowel used in CURE words, whatever it has been till now, is tending to be leveled to the [o:] of NORTH-FORCE, just as in RP". In Cockney, for example, the tendency is also for CURE to merge with

\footnotetext{
${ }^{7}$ Henceforth abbreviated simply to THOUGHT as a result of the fact that THOUGHT, NORTH and FORCE have been merged, via the First FORCE Merger, practically everywhere in the English-speaking world, "except in some provincial, Celtic, West Indian, and American accents" (Wells 1982:236) and old-fashioned RP. Thus in contemporary RP, as in the three main Southern Hemisphere varieties, the vowels in caught (THOUGHT), short (NORTH) and sport (FORCE) are homophonous.

${ }^{8}$ While, according to Wells (1982:162-163), "a phonetically identical [ひə] also arises in RP from the sequence /u:ə/ through the process of Smoothing, e.g. fewer [...] [fjoə]", and thus also conceivably in SAfE, this phenomenon is ignored in the current analysis.
} 
THOUGHT (Wells 1982:305), although in this case the merger is with /o:/ or /oə/ as a result of the so-called "THOUGHT-Split".

However, the partial nature of the Second FORCE Merger in many accents needs to be stressed. Thus, Wells (1982:287-288), in relation to RP, mentions that "words in which the vowel is preceded by a consonant plus yod [i.e. CURE following a [j] in $\mathrm{C}_{-} \mathrm{V}$ position] are relatively resistant to the shift from /oə/ to / :/, e.g. pure, furious, and cure itself; this means that there is a certain tendency to make [णə] a positional allophone of $/ \mathrm{s} / /$, as restricted to the environment $\mathrm{Cj}$ _" ${ }^{10}$. Still, the gradual merger in RP with THOUGHT is clear from comments such as the following by Wells (1982:288; note that these words were written over 30 years ago):

The result is in any case to preserve [ひə] as a phonetic option in RP, even though its phonemic status is beginning to become dubious. In beginners' phonetics classes for native English speakers [...] it is becoming increasingly difficult to find a satisfactory keyword for $/ \mathrm{v} /$, since any given word may be pronounced with /o:/ by over half the class.

CURE does not, however, only have a "relationship" with THOUGHT. In many English accents, there is an overlap with GOOSE; thus Wells (1982:164) mentions that "a phonemic identification can be made with the /u(:)/ of GOOSE, e.g. Scottish /'fjure/ fury [in] Scotland, Ireland, some parts of England and Wales, and perhaps in some American eastern speech". In contexts where CURE does not precede a prevocalic /r/ (as in Wells' example of fury above), a disyllabic sequence of GOOSE and schwa is not uncommon: "the vowel of insure, tour is sometimes to be identified with the /u(:)/ of GOOSE [...] plus - in non-rhotic accents - the vowel /ə/, giving a disyllabic sequence". Wells (1982:504) also mentions that in New York "all the centering diphthongs have monophthongal variants [which] occur most readily in the environment of a following intervocalic consonant within a word, as [in] curious", i.e. with a [ひ:]. In the case of AusE, Wells (1982:600) claims that "in the environment_rV, as security, Broad Australian typically has a quality to be identified as /u:/".

More importantly for the purposes of this paper, there is evidence from the English-speaking world of partial merger with the NURSE lexical set. Thus both Wells $(1982: 164,339)$ and Trudgill (2004b) note that in yod-dropping East Anglia, the [0ə] vowel is commonly levelled to [3:] - the realisation of NURSE - resulting in, for example, [ $[3:]$ for sure and [p3:] for pure (the latter being homophonous with purr). Wells (1982:164) further notes that other accents of English in the United Kingdom (UK), including RP, share this as a possible realisation for CURE, though, importantly, it is restricted to post-palatal or post-palato-alveolar contexts, e.g. pure can, for example, be realised as [pj3:] but not tour as [t3:]. Other examples of homophony resulting from a partial CURE-NURSE Merger in these accents, as provided by Wells (1982:164), include surely and Shirley (both [' $\left.\int_{3}: I_{1}\right]$ ) and "your with year (if pronounced [j3:])". For RP in particular, Wells (1982:288) also provides examples such as "curious ['kj3:riəs], during ['dj3:rın 'dz3:rın]1 ${ }^{11}$, yours [j3:s]". However, Gimson (1977:xviii) dubs these cases of CURE-NURSE overlap in RP "too idiosyncratic to warrant inclusion" in any formal description of the accent, an analysis which Wells (1982) supports.

\footnotetext{
9 This is not relevant to the current discussion; more can be gleaned from Wells (1982:310-311).

${ }^{10}$ An important detail here is Wells' (1982:288) claim that "where the yod is word-initial, /o:/ is frequent, as in your-you're /jo:/, Europe, Ural'.

${ }^{11}$ Here with SAfE-like yod assimilation.
} 
A similar trend has also been observed in certain rhotic North American accents. Again, Wells $(1982: 164,484)$ provides the example of homophonous surely and Shirley, [ 33 li], as not uncommon in the varieties of the United States of America (USA), including GenAm. Relatedly, in Iowa, Nebraska and Minnesota ${ }^{12}$, there have been attestations of the realisation $\left[\int \gamma^{\circ}\right]$ for sure. Likewise, "Europeans notice the way some Americans seem to pronounce Europe as 'Yurrup', i.e. /'j3rəp/ rather than the expected /'jorəp/ (compare RP /'joərəp 'jo:rəp/)" (Wells 1982:484). Thomas (2004:314) indicates that a CURE-NURSE Merger occurs frequently in the speech of young people in Texas and Missouri. The realisation [ə] also appears to be used more often after [j] and in non-final syllables, such as in tournament, than elsewhere. However, Thomas (2004:314) cautions that this merger "tends to show considerable style shifting" and occurs most frequently when the speaker's attention is not drawn to it.

\subsection{CURE in South African English}

Traditional descriptions of SAfE have indicated that its speakers, like those of conservative RP, pronounce the CURE vowel using the diphthong [चə] as in poor [pひə]. Many authors have, however, also noticed a divergence in SAfE from this traditional pronunciation, both in the direction of THOUGHT and GOOSE.

Relatively early accounts of SAfE describe a tendency towards monophthongisation of CURE. The early Hopwood (1928:19) gives, for example, "tour 'to $\boldsymbol{\partial}>$ " too(r)" tù r (or "tewr" tÿür)". Lanham and Traill (1962:31-32), for example, indicate that words in the CURE and THOUGHT lexical sets may often be homophonous and Lanham (1965:319) claims a tendency towards monophthongisation and a replacement of " $/ \mathrm{u}^{2} /$ with either $/ \mathrm{u} /$ or $/ \mathrm{s} /$ ". Therefore, according to this author, "sure, poor are hardly ever $/ \mathrm{s}^{2} /$ and $/ \mathrm{pu}^{2} /$ in this country; but $/ \mathrm{s}^{\circ} \% /$ and $/ \mathrm{po}^{2} /$ " (Lanham 1965:92). Lanham (1967) gives examples such as /kru:l/ and /dzu:lri/ for cruel and jewelry for the replacement of CURE by GOOSE. He (1967:94) also mentions the possibility of disyllabic variants $/ u+2 /$ in the most extreme forms of SAfE.

Lass (1990:278-279) gives [̈̈ə] as the quality of CURE but contends that in GenSAfE the "CURE/THOUGHT contrast is not entirely stable: many speakers (especially younger ones) have a variable merger with THOUGHT". This author emphasises the quality of the word sure, which he describes as being particularly susceptible to this "variable merger", and thus often realised as [Jo:]. According to Lass (1995:100-101), the CURE vowel is in the process, particularly among BrSAfE and younger GenSAfE speakers, of merging with THOUGHT, which accounts for the homophony between your and yore as well as shore and sure in SAfE. However, it is unclear how extensive this merger is or what its social value is. What is certain is that a /(C) j_/ context, as in fury, pure and cure, appears to be resistant to the merger. In BrSAfE, and in cases where THOUGHT has transplanted CURE, there is also the occasional monophthongisation to a GOOSE-like quality, "especially in the contraction you're" (Lass 1995:101), as is reflected in Hopwood (1928). Branford (1994:482) also claims that /və/ is increasingly being replaced by / $/$. Lass (2002) points to a nascent Second FORCE Merger, while Lass (2004:378) confirms the distinction between CURE and THOUGHT in SAfE, although he labels this distinction recessive and makes the claim that with respect to "words with final historical /r/ (e.g. sure vs. shore) [...] speakers in their twenties rarely make the distinction". In line with much else in the literature, Bailey (1984:16) claims that CURE is being

\footnotetext{
${ }^{12}$ Bob Dylan's birth state.
} 
eliminated in SAfE and being replaced with the vowel of THOUGHT. Bowerman (2004:939) confirms that there is at least a partial merger in GenSAfE with THOUGHT, particularly when in an environment with no preceding yod, i.e. [j]: “[...] there is a growing trend, especially when the vowel does not occur after /j/ (sure), in General toward Broad's monophthongal [o:], perhaps slightly lower than THOUGHT". In contrast, Trudgill (2004a:145) attests that the Second FORCE Merger appears "to be absent, so far, from South African English".

Figures 2 and 3 provide acoustic data from Bekker (2009) relating to CURE ${ }^{13}$. In the case of both figures, the representation is based on an analysis of 62 tokens altogether of the words cure, pure, poor and moor. In the case of Figure 2, data from RP is also provided ${ }^{14}$.

Evidence for a glide-weakened monophthongal value in the RP data is clear, but the same does not apply to SAfE where we have what looks like a glide from a high-central to mid-central position [нə]. The following clarification is provided in Bekker (2009:325, 329):

The rather unexpected starting-point for this vowel [...] is, however, clarified if we view the tokens mentioned above separately [see Figure 3 of the current paper]. Here we note the movement of cure and pure (with a preceding yod) from a highfront to a schwa position ${ }^{15}$, while the remaining two tokens (poor and moor) move clearly from a high back position to mid-central. There is no evidence here for a CURE-THOUGHT Merger i.e. for the Second FORCE Merger.

The acoustic data thus provides evidence for two positional, fully diphthongal allophones of GenSAfE: [Yə] after a palatal segment (in all likelihood, a direct result of accommodation to the palatal segment) and the canonical [ひə] in other contexts.

From my own impressionistic observations, it appears that the CURE vowel in GenSAfE is also characterised by a partial merger with the NURSE lexical set. However, the impressionistic literature on SAfE as well as the analysis provided by Bekker (2009) (and as reflected in Figures 2 and 3) provide little evidence for such a partial merger and, consequently, other evidence will be required to verify this impression.

\footnotetext{
${ }^{13}$ There were 29 subjects in Bekker (2009) and the data was collected in wordlist style. The subjects were female, white, young and decidedly middle-class, i.e. GenSAfE-speakers and identical to many of the subjects recorded for this analysis - see section 4. A Praat script (Boersma and Weenink 2013) was written in order to allow the author to take 10 evenly-spaced measurements in time per formant (F1 and F2). This allowed the capturing of vowel-internal spectral movement. The standard deviation (represented in the various figures as ellipses) is that of the temporal midpoint of each vowel or vowel allophone. More methodological issues are covered in Bekker (2009) and, in particular, in Chapter 4.

${ }^{14}$ Drawn from Cruttenden (2001); the first diphthongal target (i.e. the nucleus) has been labelled as "R1", while the second diphthongal target (i.e. the glide) has been labelled as "R2".

15 The two labels overlap so the "picture" is a little obscured in this regard.
} 


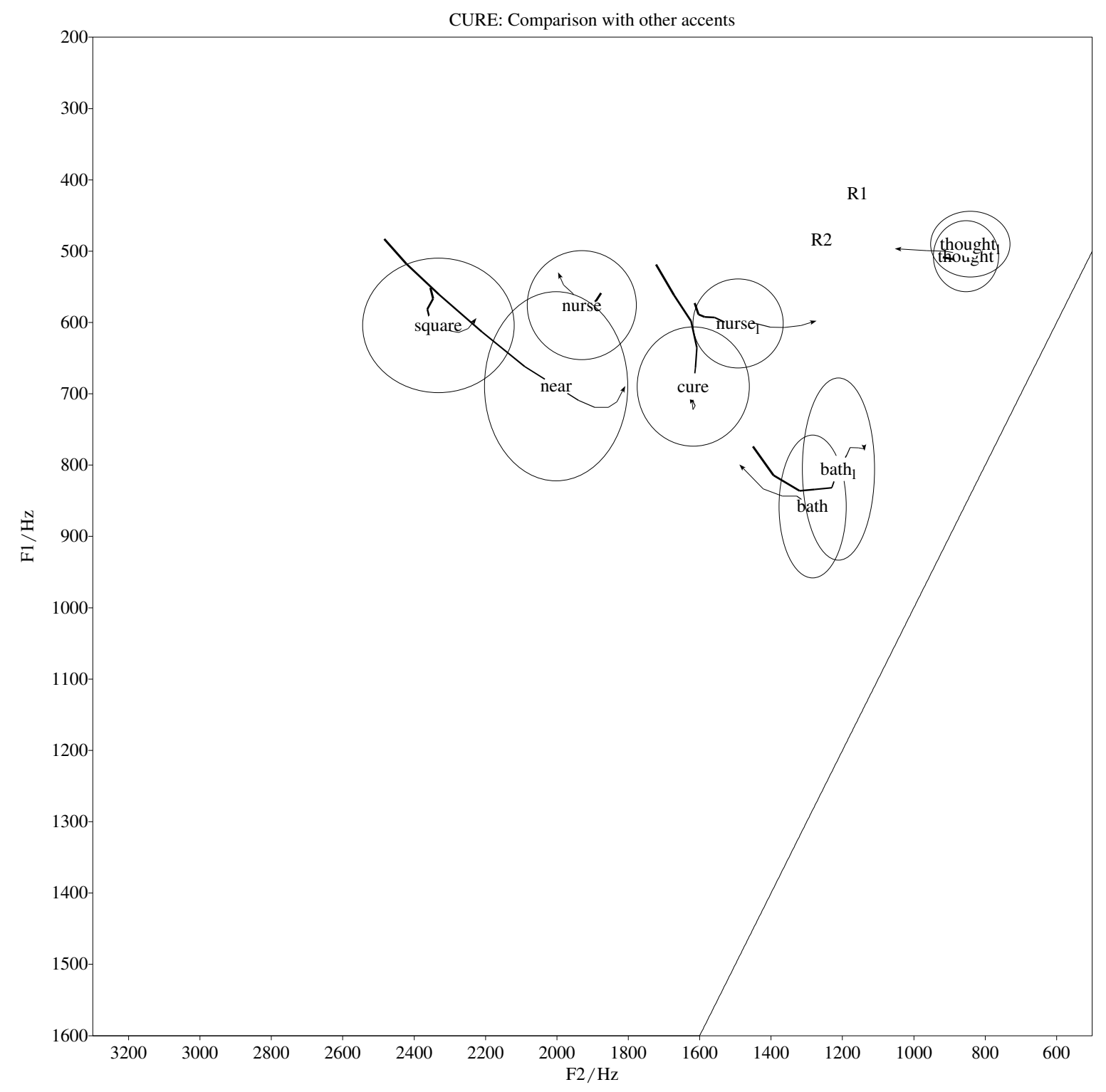

Figure 2. SAfE CURE in the context of other SAfE vowels and RP CURE 


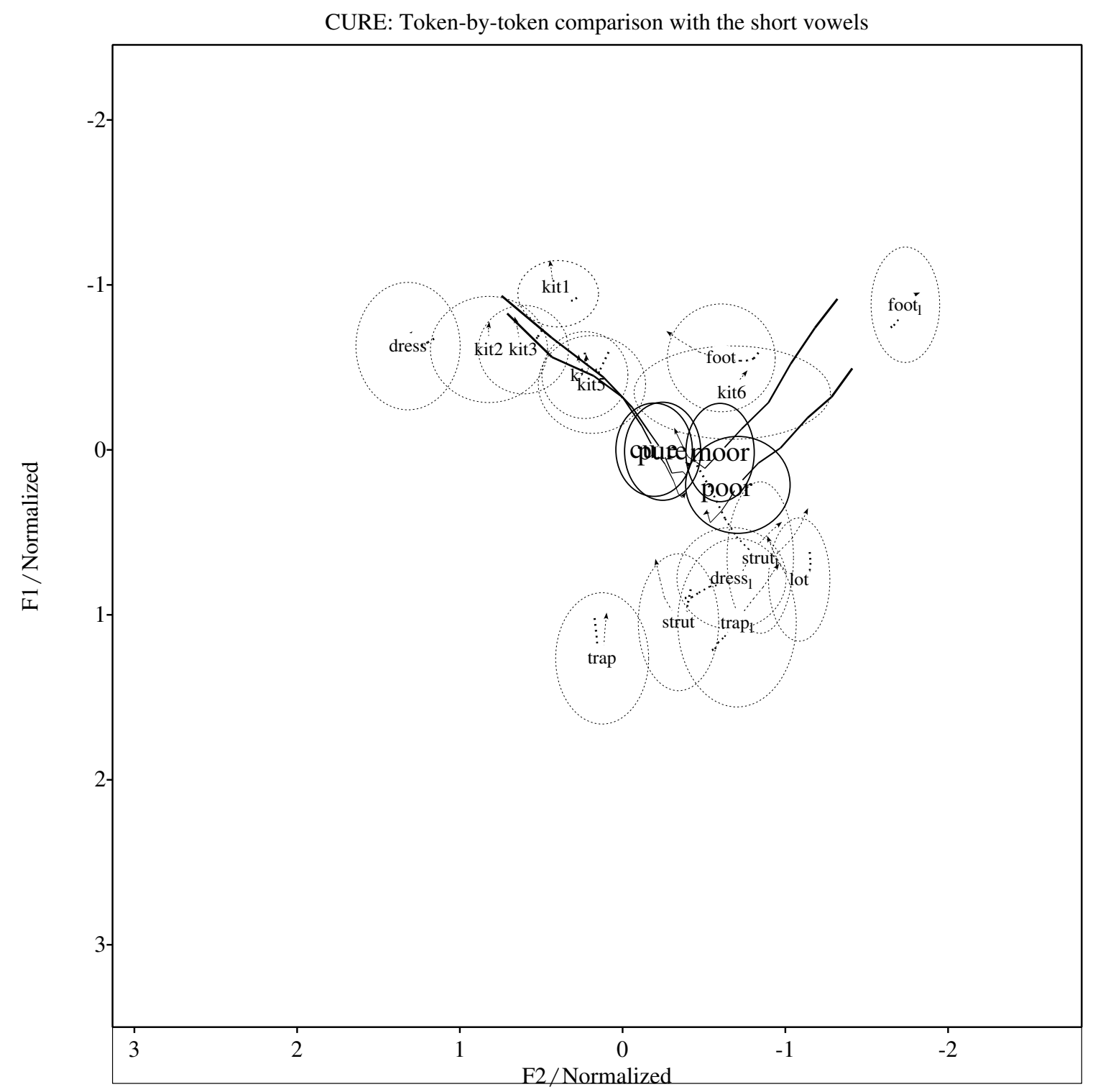

Figure 3. Token-by-token comparison of SAfE CURE words (Bekker 2009)

The hypothesis that will thus be tested in this article is that such a partial CURE-NURSE Merger is evident in the speech of GenSAfE speakers. The value at which the merger is taking place is a somewhat centralised [ $\varnothing:]$, narrowly [ $\ddot{\varnothing}:]$, the general value for NURSE in SAfE, as opposed to the unrounded RP [3:], which is rarely found in the speech of GenSAfE speakers (Branford 1994).

\section{Methodology and data collection}

Of course, it is possible, even likely, that the realisation of CURE in GenSAfE depends on social variables such as gender and age. The current research was modest in its ambitions in that it was decided for the most part to restrict the influence of these social variables rather than incorporate them directly into the research design, i.e. the focus was to first test for the existence and system-internal pattern of any partial CURE-NURSE Merger and to leave studying its 
variability in the speech community to a later stage ${ }^{16}$. As such, the first round of data collection (RR1) involved the collection of recordings of acoustic data from a relatively homogenous group of six white females between the ages of 17 and 20. The participants were all born in South Africa, are L1-English speakers, and are first-year students at Rhodes University in Grahamstown, a prestigious South African higher-education institution largely comprising members of the middle- to upper-middle classes. In order to further ensure homogeneity vis-àvis class, all subjects were required to have attended private secondary schools in South Africa. The use of subjects from private schools intensified the focus and control of the study while also adding to the homogeneity of the group being studied.

The participants were briefed and told that they would be taking part in a linguistics research project and that their voices would be recorded. The specific variables of interest were, however, not discussed in order to minimise the possible effects of the observer's paradox. They were then asked to sign a consent form, in which they were given details about how the recordings would be used for research purposes, and were told that they were in no way obligated to continue with the research if they did not wish to do so.

During RR1, participants were only required to read aloud a wordlist and reading passage (see Appendix A1 and A2 where the CURE words are underlined). More naturalistic data was not elicited since words in the CURE lexical set generally have a low incidence rate. Further research in this area would add significantly to findings since, as Thomas (2004) states, some variants are often only perceived in more informal styles. The participants' speech was digitally recorded in a sound-attenuated room in the Department of English Language and Linguistics at Rhodes University. In the case of the wordlist, the words from the various lexical sets were arranged in a random fashion and were presented individually to the participants on cue cards in order to prevent list intonation. Other words in the list and reading passage were used to elicit acoustic data in order to aid the comparison of CURE with other vowels in the SAfE vowel system, if necessary. Specifically, 10 words from the NURSE lexical set were listed in order to allow a comparison between the realisations of this vowel and CURE. In order to minimise the effects of coarticulation on the vowels, where possible and where practicable, words with voiceless stops and fricatives in the surrounding environment were used ${ }^{17}$. The reading passage was created specifically for this study and contained a further 10 words from the CURE lexical set (see Appendix A2).

The majority of words in RR1 contained CURE following a [j] in C_V position (i.e. a yod), as in pure, but also in _V position, as in Europe, as well as following a palato-alveolar sound, as in assure. In contrast, the second round of recordings (RR2) was more focused on CURE in non-post-palatal position (e.g. tour, poor, moor). In addition, it was also decided that, for this round, speakers from two separate generations would be recorded. Participants were restricted to white, female, L1-English speakers from middle-class backgrounds who were born in the Eastern Cape province of South Africa. The younger group consisted of five female Rhodes University students between the ages of 18 and 22, while the older group was composed of five women over the age of 40 .

\footnotetext{
${ }^{16}$ The exception to this is that, for the second recording round (see below), data was drawn from two separate generations of speakers.

${ }^{17}$ In the case of the CURE tokens themselves, however, there were substantial restrictions in this regard, mainly due to the low lexical incidence of this vowel in English.
} 
The relevant wordlist contained nine words from the CURE lexical set (see Appendix B1), most without preceding yods, palatals or palato-alveolar sounds and most containing the vowel in primary stressed position. Ten words from the NURSE lexical set, amongst others, were listed in order to aid comparison. A different reading passage (see Appendix B2) was, once again, created specifically for this research project, and included a further five words containing the CURE vowel in non-post-palatal position.

\section{Results}

The following sections provide the results for the current study. Sections 5.1 and 5.2 are focused on providing impressionistic and acoustic evidence respectively, for RR1, while sections 5.3 and 5.4 are similarly linked to RR2.

\subsection{RR1: Impressionistic results}

Table 1 provides the impressionistic results relating to RR1. Included alongside the SAfE data in column five are the RP and GenAm pronunciations as contained in the Oxford English Dictionary ("OED" in Tables 1-3) as well as Wells' (2008) Longman Pronunciation Dictionary ${ }^{18}$ ("LPD" in Tables 1-3). In the majority of the cases, CURE appears in a post-yod (e.g. obscure), post-palatal (e.g. Europe) or post-palato-alveolar context (e.g. insurance) ${ }^{19}$. Where this is not the case, the words have been bolded in the first column (i.e. poor and tour). In addition, where CURE traditionally occurs in a non-primary-stressed syllable, the relevant word has been italicised. Information regarding whether or not the word occurred in citation form or as part of the reading passage is included in the second column (CF = Citation Form; $\mathrm{RD}=$ Reading Passage). Where an RP or GenAm pronunciation shows CURE-NURSE homophony, this pronunciation has been bolded in columns three and four respectively. In the case of the SAfE pronunciations in column five, the numbers in brackets indicate the incidence of minority pronunciations, e.g. in the case of assure, five of the speakers pronounced the word as [ə'fひə], while only one pronounced it as [ə'Jjvə]. Where the CURE vowel occurs in a wordinternal position (e.g. in surely as opposed to sure), the relevant row has been shaded.

Table 1. Information relating to CURE words in Recording Round 1 (RR1)

\begin{tabular}{|c|c|c|c|c|}
\hline Word & CF/RD & OED & LPD & SAfE \\
\hline obscure & $\mathrm{CF}$ & $\begin{array}{l}\text { 'skjuə/' skjo: } \\
\text { 'skjv(ə)r }\end{array}$ & 'skjuə/' skjo: 'skjvr & 'skjuə \\
\hline brochure & $\mathrm{CF}$ & 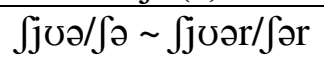 & 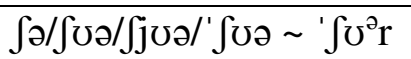 & ' \\
\hline venture & $\mathrm{CF}$ & 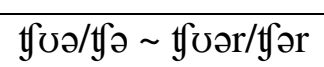 & $\mathrm{t} \partial \sim \mathrm{t}^{\rho} \mathrm{r}$ & to \\
\hline Europe & $\mathrm{CF}$ & 'jvə/'jэ: 'jə/'ju & 'jvə/'jo: 'jv/' j3: & jø: \\
\hline
\end{tabular}

\footnotetext{
${ }^{18}$ A transcription is provided only for the relevant syllable in which the CURE vowel is found in the relevant word. RP and GenAm pronunciations are divided by a ' ' sign; alternative pronunciations within each of these two accents are indicated by a ' $/$ ' and are provided in order of prevalence.

${ }^{19}$ Often simply referred to as "post-palatal" as a cover-term in what follows; where the necessary distinctions are relevant, they will be made clear.

${ }^{20}$ Unlike the two reference accents, it would appear that brochure in GenSAfE generally has primary-stress on the second syllable.
} 


\begin{tabular}{|c|c|c|c|c|}
\hline assure & $\mathrm{CF}$ & ' Juə ' 'vər & 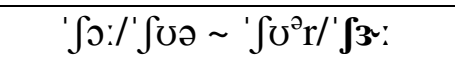 & 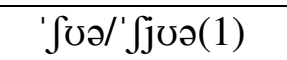 \\
\hline luxurious & $\mathrm{CF}$ & 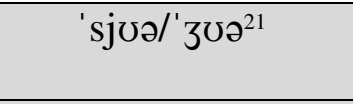 & $\begin{array}{c}\text { 'zoə/' Juə/' zjuə/' sjuə } \\
\text { zur/' Jur }\end{array}$ & '3ø: \\
\hline fury & $\mathrm{CF}$ & 'fjuə & 'fjoə/' fjo: 'fjor & 'fjø:/'fø:(1) \\
\hline incurable & $\mathrm{CF}$ & 'kjøə & 'kjøə/'kjə: 'kjor & 'kjø: \\
\hline neuron & $\mathrm{CF}$ & njøə 'n(j)v & 'njøə/'njo: 'nø/' njo/' nju: & 'njø:/'nju:(2) \\
\hline poor & $\mathrm{CF}$ & $\begin{array}{l}\text { 'pvə/'po: } \\
\text { 'pv(ə)r/'po(ə)r }\end{array}$ & 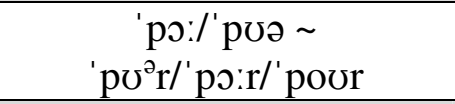 & 'рøə/po:(1) \\
\hline plural & $\mathrm{CF}$ & 'pløə/'plっ: 'plひ & 'pløə/'plっ: 'plひ & plø:23 \\
\hline pure & $\mathrm{CF}$ & 'pjøə/'pjo: 'pjø(ə) & 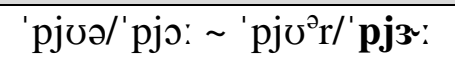 & ' pjø: \\
\hline mural & $\mathrm{CF}$ & 'mjøə/'mjs: 'mju & 'mjøə/'mjs: 'mju & 'mjv(5)/' mjø:(1) \\
\hline mature & $\mathrm{CF}$ & 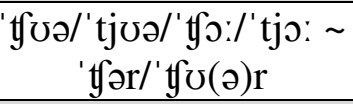 & 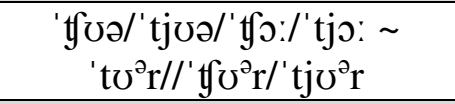 & 'tøə \\
\hline curious & $\mathrm{CF}$ & 'kjøə & 'kjuə/'kjo: 'kjor & 'kjø: \\
\hline insurance & $\mathrm{CF}$ & ' Jü & 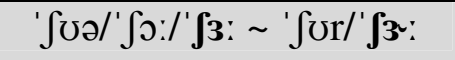 & 'Јø:/' sjø: (1) \\
\hline sure & $\mathrm{RD}$ & 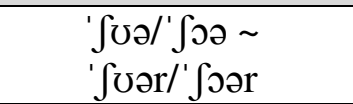 & 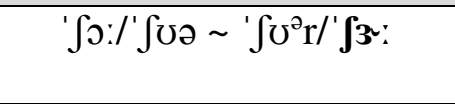 & ' ઈचə/' fo:(1) \\
\hline manicure & $\mathrm{RD}$ & kjøə/kjo: kjø(ə)r & kjøə/kjə: kjør/kjза: & kjø:/kjə(2) \\
\hline fixture & $\mathrm{RD}$ & Stjoə stjvər & $\mathrm{t} \partial \sim \mathrm{t}^{9} \mathrm{r}$ & to \\
\hline insecure & $\mathrm{RD}$ & 'kjøə 'kjøər & 'kjøə/'kjə: 'kjఠr & 'kjø:(3)/'kj3:(3) \\
\hline infuriating & $\mathrm{RD}$ & 'fjuə & 'fjuə/'fjo: 'fjor & 'fjø: \\
\hline tour & $\mathrm{RD}$ & 'toə 'toər & 'tvə/' to: 'tvr & 'tuə/' toə(1) \\
\hline surely & RD & 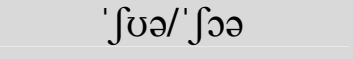 & 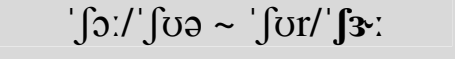 & ' $\varnothing:$ \\
\hline reassuring & $\mathrm{RD}$ & 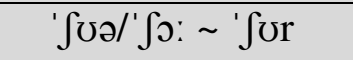 & 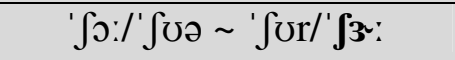 & ' $\varnothing:$ \\
\hline jury & RD & 'dzणə & 'dzणə/' dzз:/' dzo: 'dzor & 'd \\
\hline cure & $\mathrm{RD}$ & 'kjøə 'kjøər & 'kjøə/'kjo: 'kjoərr & 'kjø:/'kjз:(2) \\
\hline
\end{tabular}

In terms of the SAfE data, what is noticeable in Table 1 is the degree of variability when it comes to the realisation of the CURE vowel. There are, however, some trends which one can extrapolate. Firstly, in comparison to the two reference accents, a NURSE vowel or [ $\varnothing$ :]-quality is often used where an [və]-quality is generally expected. The tendency for CURE to undergo

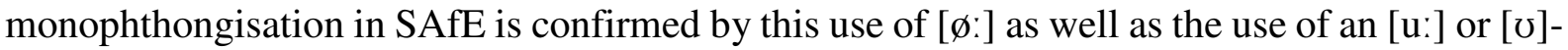

\footnotetext{
${ }^{21}$ The OED only provides one pronunciation for luxurious as well as other words, such as fury and incurable. The implication is, presumably, that both RP and GenAm are identical in these cases.

22 This was, in all likelihood, a mis-reading of the word, i.e. furry for fury.

${ }^{23}$ The token plural is designated "post-palatal" given the fact that SAfE, like RP, has a clear-dark /1/ allophony, i.e. /l/ is clearly fronted (palatal) in initial position.
} 
quality in certain cases (e.g. in neuron and mural) and by the few cases of Second FORCE Merger [o:] (one case each of poor, sure and jury) ${ }^{24}$. These cases provide support for the impression that SAfE is not accelerating in the direction of the Second FORCE Merger and that the few cases of an [o:]-quality are not found in post-yod position ${ }^{25}$. The other tendency that appears to be apparent in the data is for a NURSE-like quality to be particularly prevalent in positions where the syllable containing the CURE vowel is in word-internal as opposed to wordfinal position. In Table 1, for example, all examples of CURE in a word-internal position use a

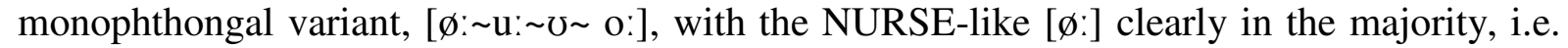
only 8 out of 78 tokens did not use this quality with respect to only 3 out of the 13 words, e.g. neuron (two uses of [u:]), mural (five uses of [v]) and jury (one use of [o:]). Importantly, the fully diphthongal [णə] appears in none of the cases of CURE in word-internal position. On the contrary, in the case of CURE in word-final position, there appears to be a high degree of variability, with [ชə], [ $\varnothing:]$ as well as the exceptional [o:] featuring. The canonical diphthongal [ซə], or at least its fronted, positional variant $[\mathrm{Yə}]^{26}$, appears to be a prominent variant. In addition, particular lexical items (e.g. obscure and pure) tend to be, at least impressionistically, reasonably regular in terms of the quality of their CURE vowel with only a couple of exceptions (e.g. sure).

\subsection{RR1: Acoustic evidence}

This section provides an analysis of some of the acoustic data drawn from the same set of words provided in Table 1. Because of the relatively intensive nature of the acoustic analysis provided, the acoustic component of the analysis is not as extensive, in terms of word coverage, as the impressionistic component and serves mainly to augment and refine some of the impressionistic observations.

Beginning with the issue of the phonotactic positioning of CURE (i.e. word-final vs. wordinternal), Figures 4a-9a provide spectrograms of the six tokens of surely (i.e. CURE in postpalatal, word-internal position) while Figures $4 \mathrm{~b}-9 \mathrm{~b}$ provide spectrograms of the six tokens of sure (i.e. CURE in post-palatal, word-final position). The heading of each figure includes the impressionistic transcription as summarised in Table 1. A comparison of these two words is particularly useful since they are, of course, identical in terms of their first (or only) syllable, except with regard to whether the syllable carrying the CURE vowel is word-internal or wordfinal. Note that both words occurred in the reading passage and both occurred in pre-pausal (sentence-final) position (see Appendix 1B).

\footnotetext{
${ }^{24}$ There is also the intermediate ['too] in one case of tour.

${ }^{25}$ This needs to be distinguished from other post-palatal contexts, i.e. the [ $\left.\int\right]$ in sure and the [d]] in jury provide a palatal context (in the general sense) but are obviously not yods, i.e. a [j] in $\mathrm{C}_{-}$context. The same applies to [j] in a _V context (e.g. in Europe), but in this case there is no evidence for an [o:]-variant.

${ }^{26}$ See again the discussion of Bekker's (2009) results in section 3.2.
} 


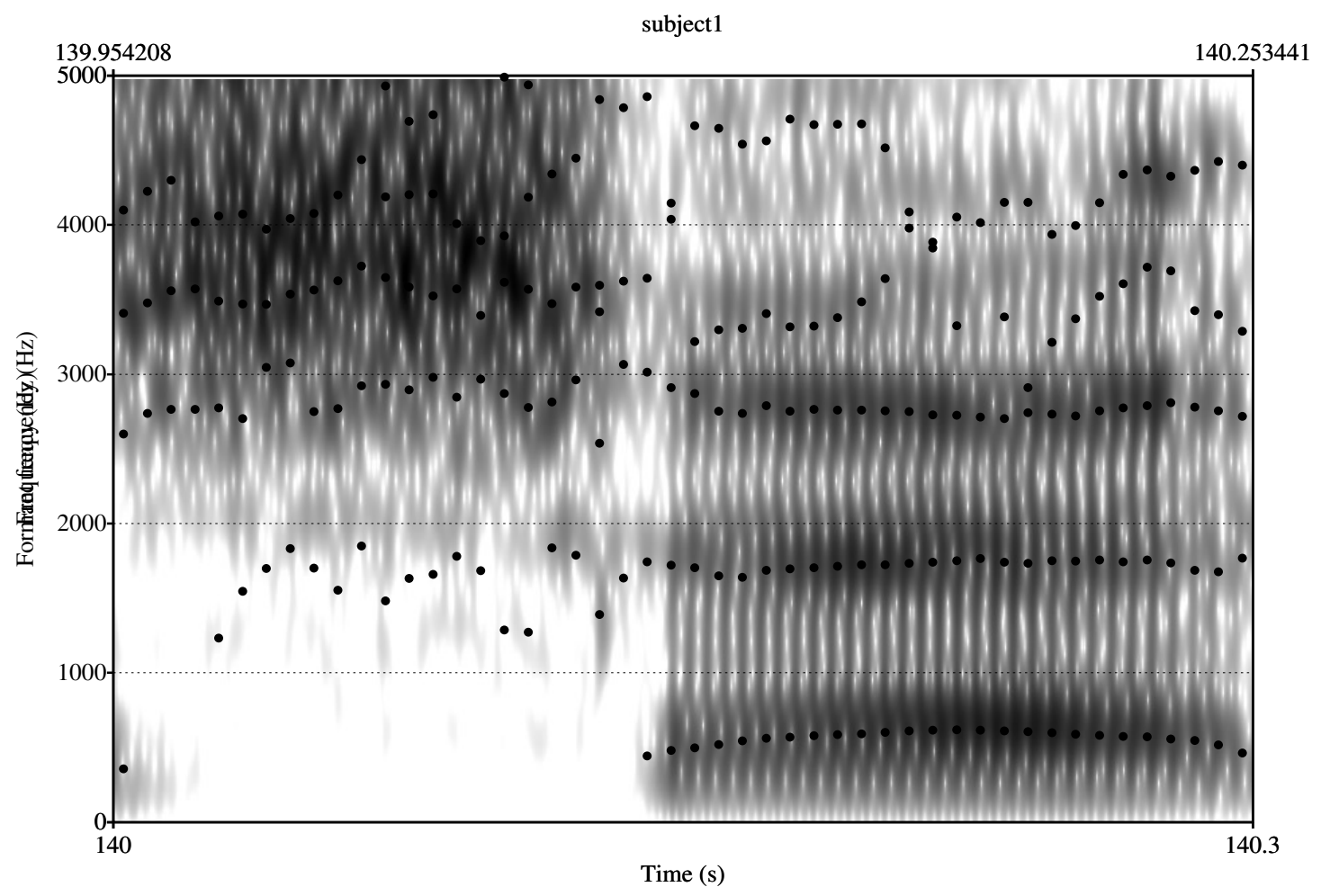

Figure 4a. Spectrogram of Subject 1's surely [' $\varnothing:]$

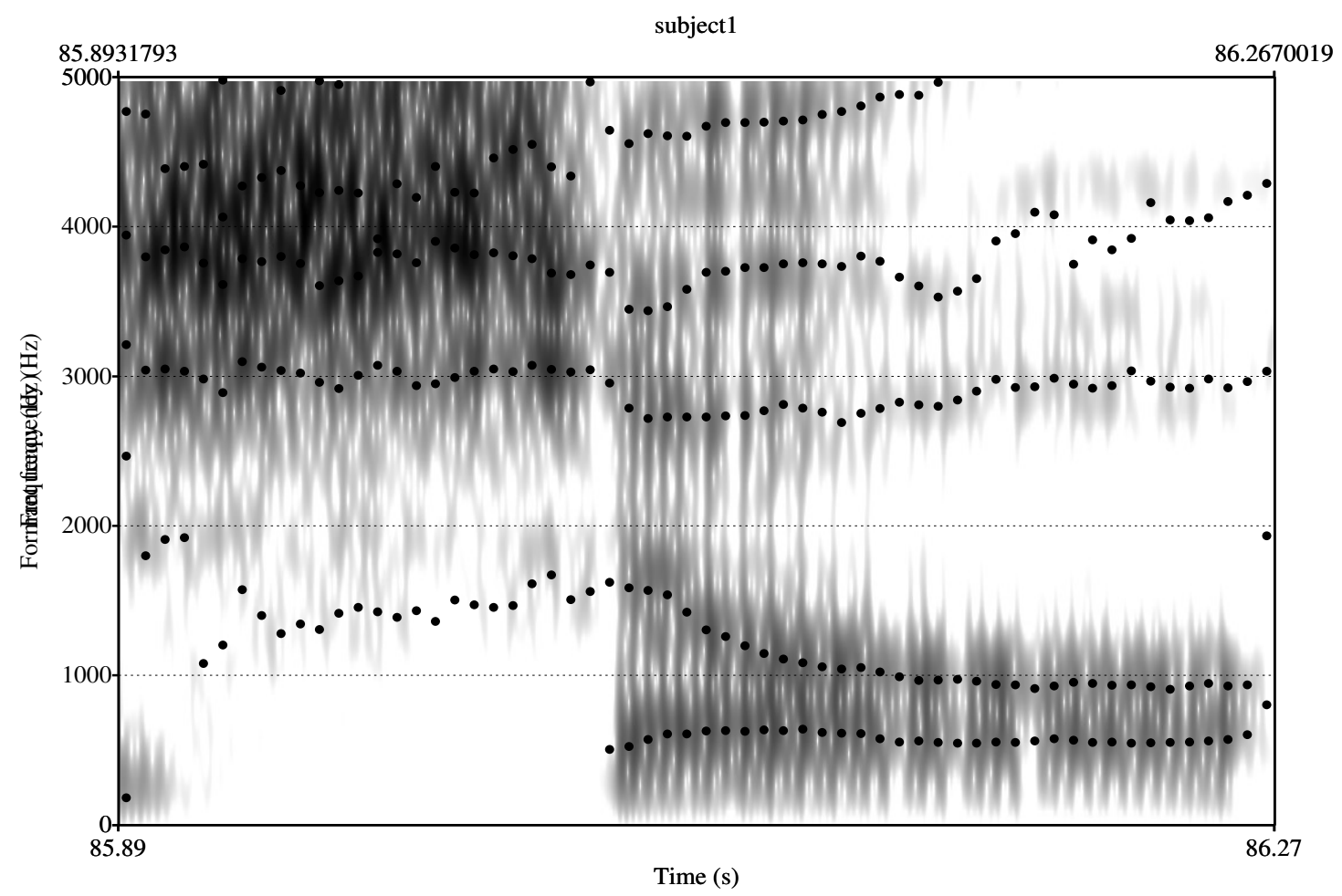

Figure 4b. Spectrogram of Subject 1's sure [' $\left.\int \mathrm{o}:\right]$ 


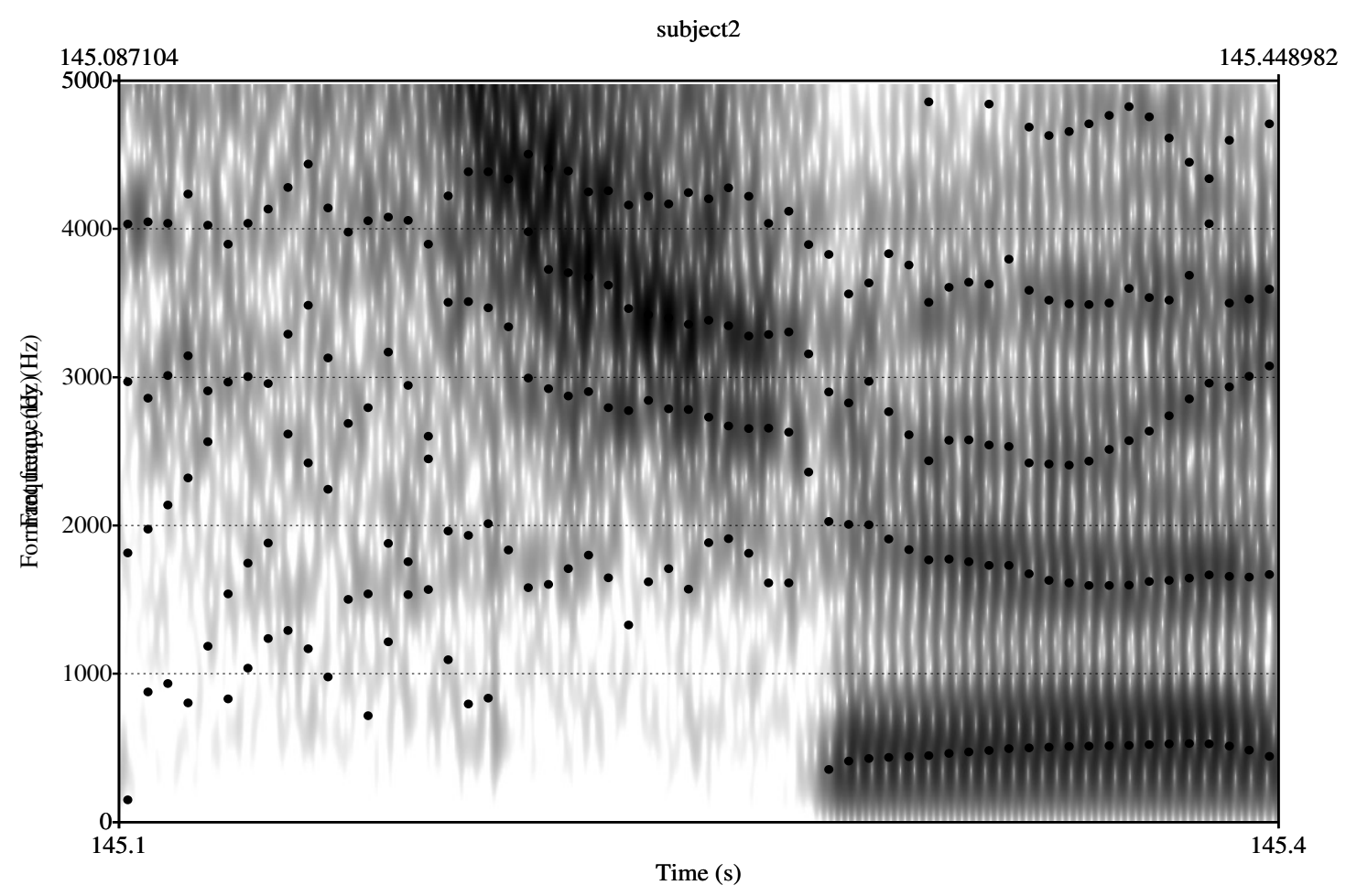

Figure 5a. Spectrogram of Subject 2's surely [' $\varnothing:]$

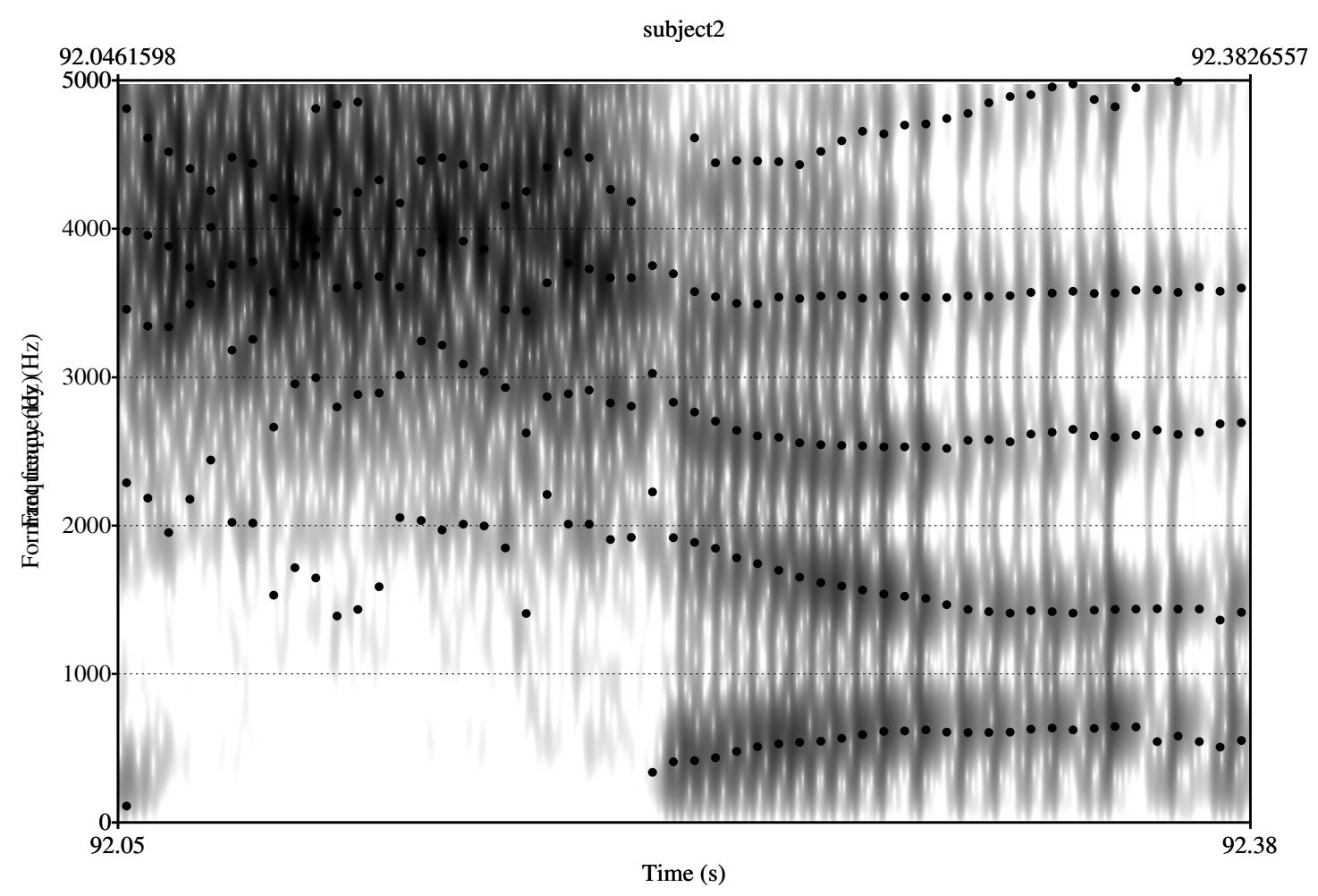

Figure 5b. Spectrogram of Subject 2's sure ['Joə] 


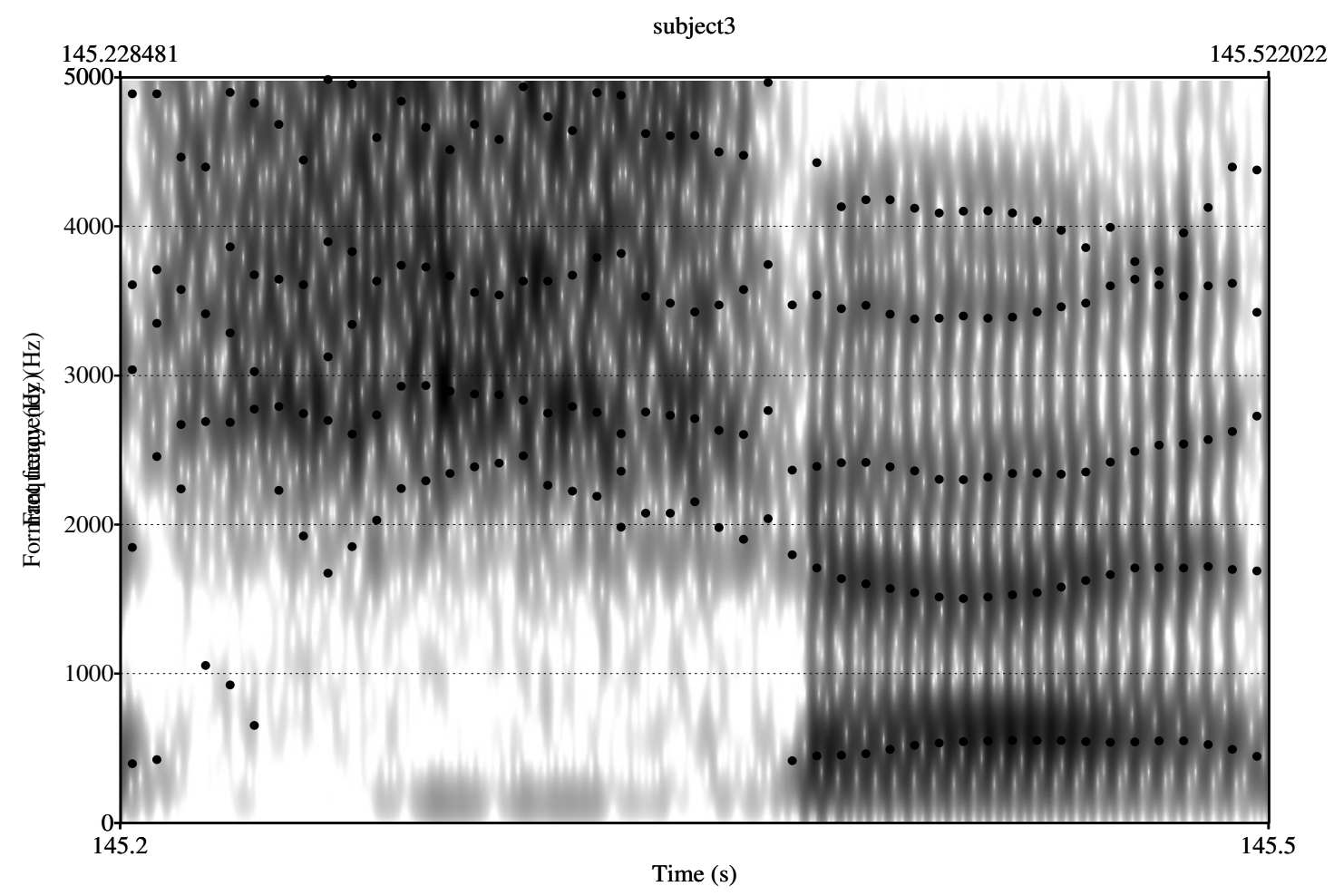

Figure 6a. Spectrogram of Subject 3's surely [' $\varnothing:]$

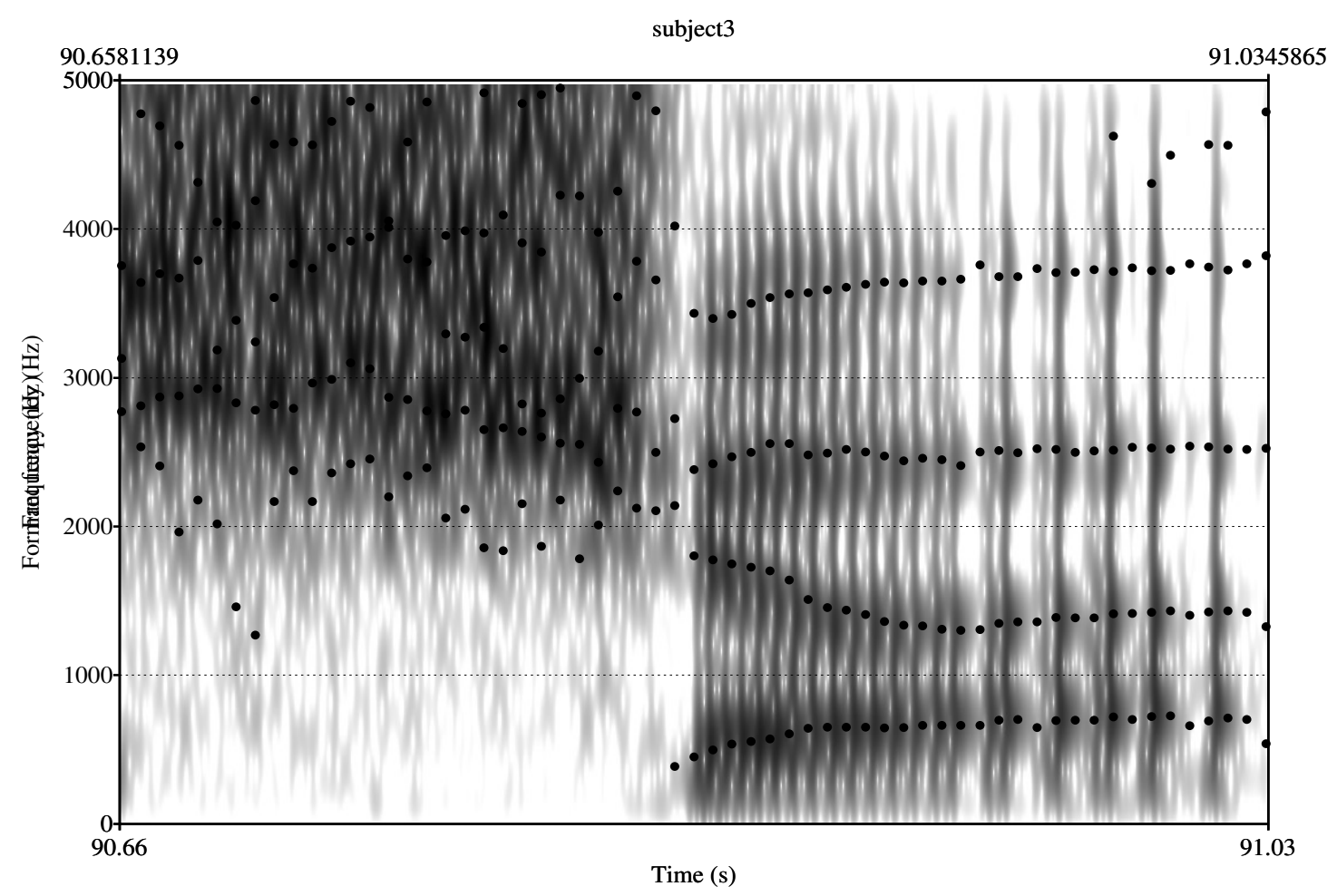

Figure 6b. Spectrogram of Subject 3's sure ['Joə] 


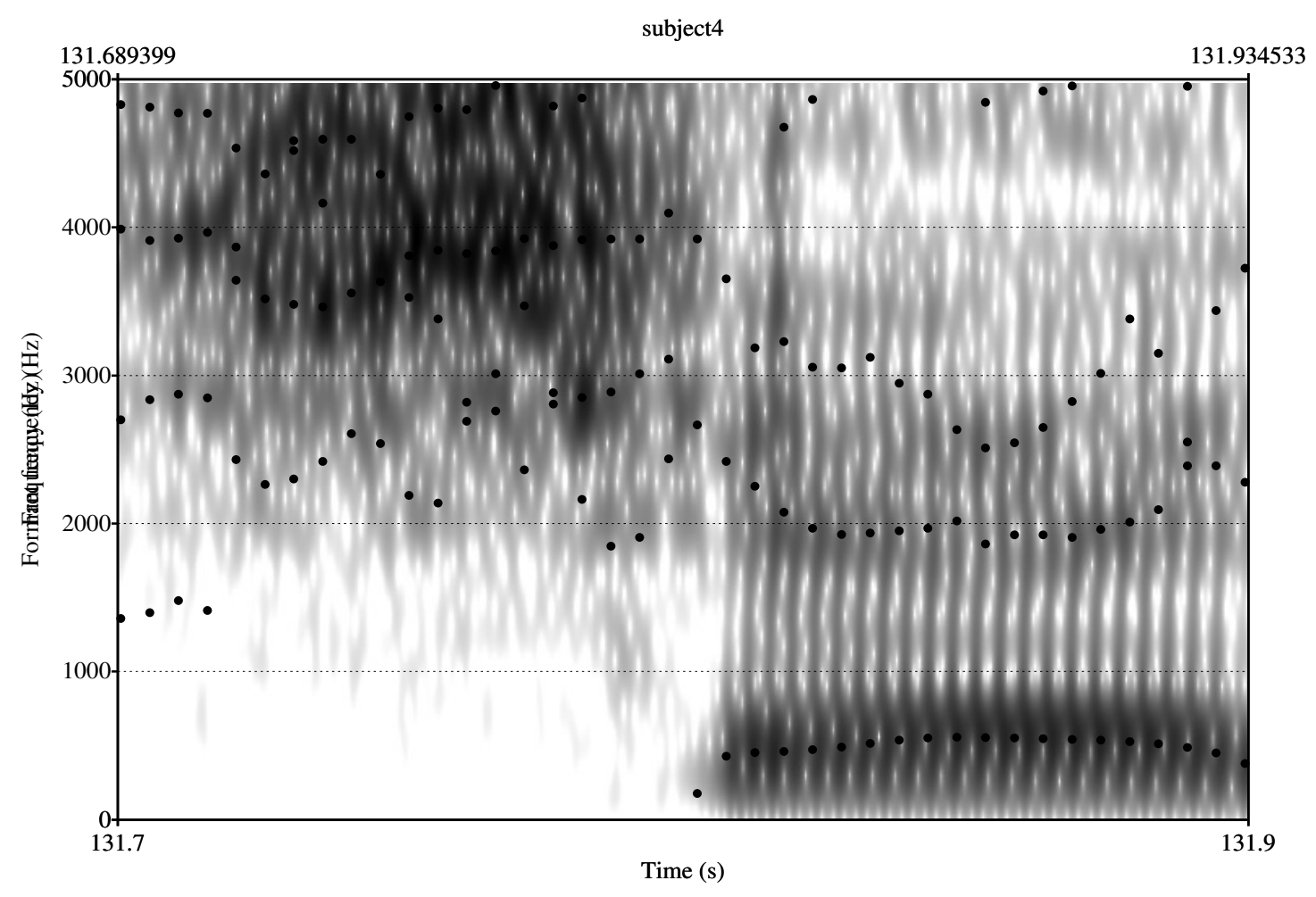

Figure 7a. Spectrogram of Subject 4's surely [' $\varnothing:]$

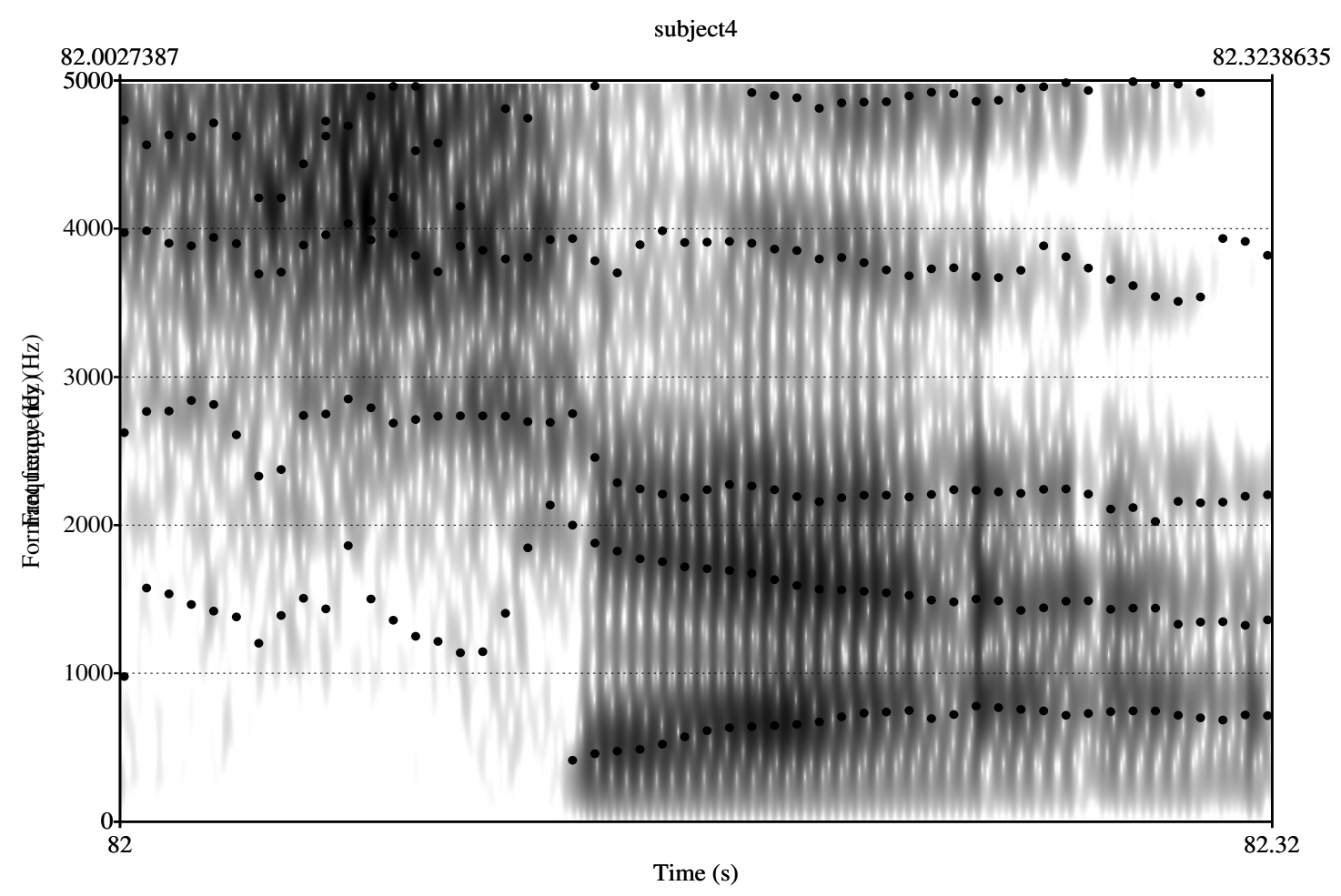

Figure 7b. Spectrogram of Subject 4's sure ['Joə] 


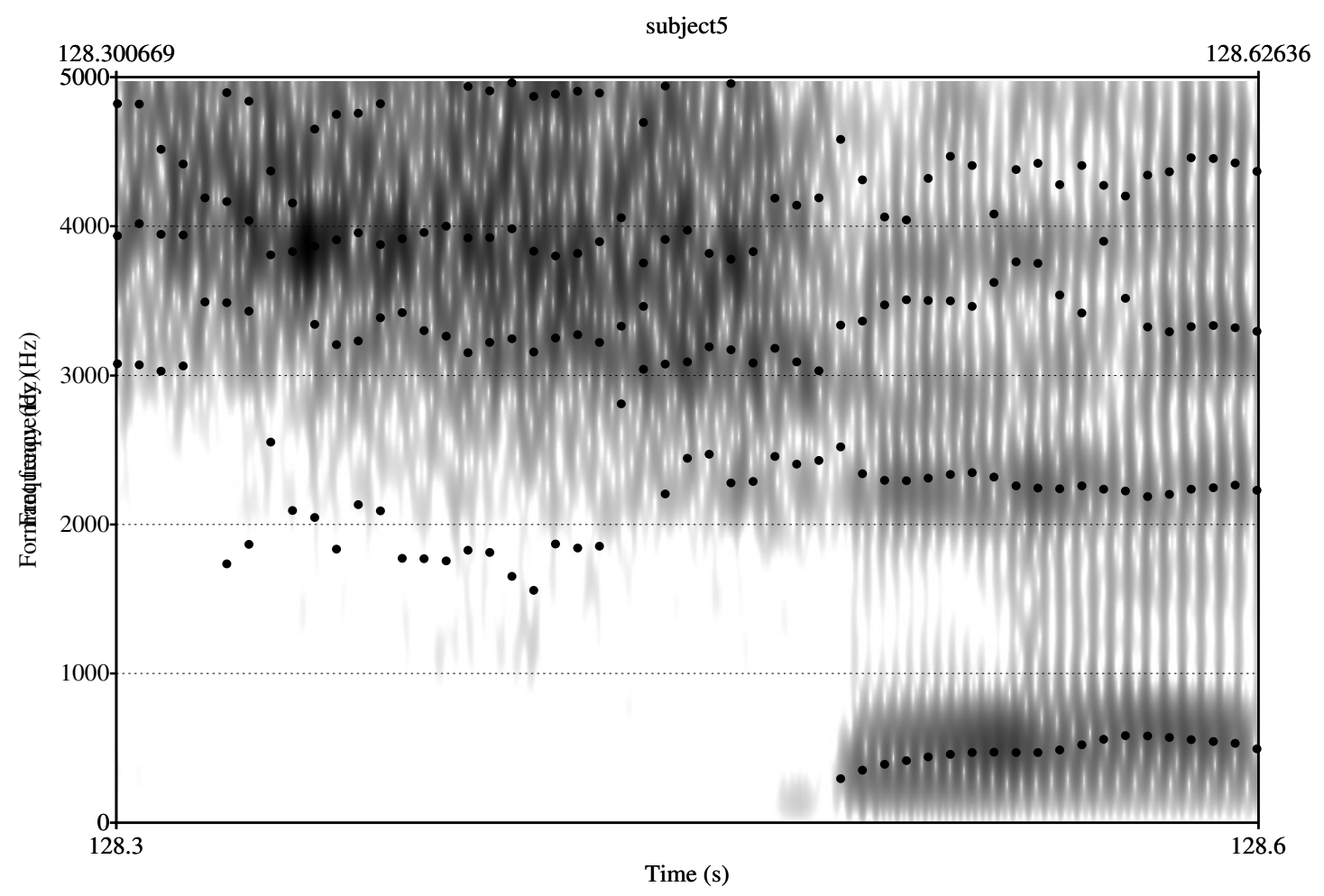

Figure 8a. Spectrogram of Subject 5's surely ['ऽø:]

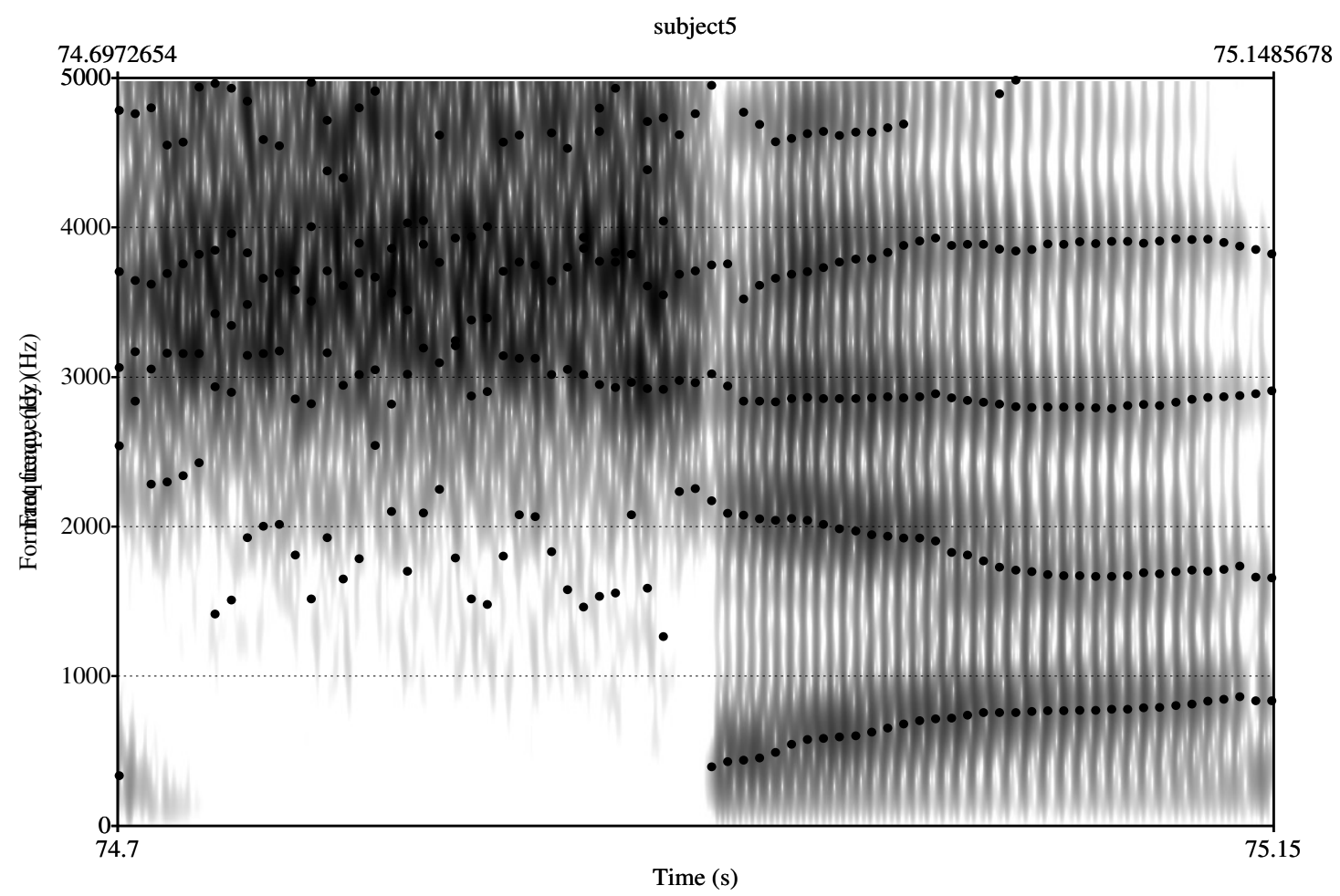

Figure 8b. Spectrogram of Subject 5's sure [' Jəə] 


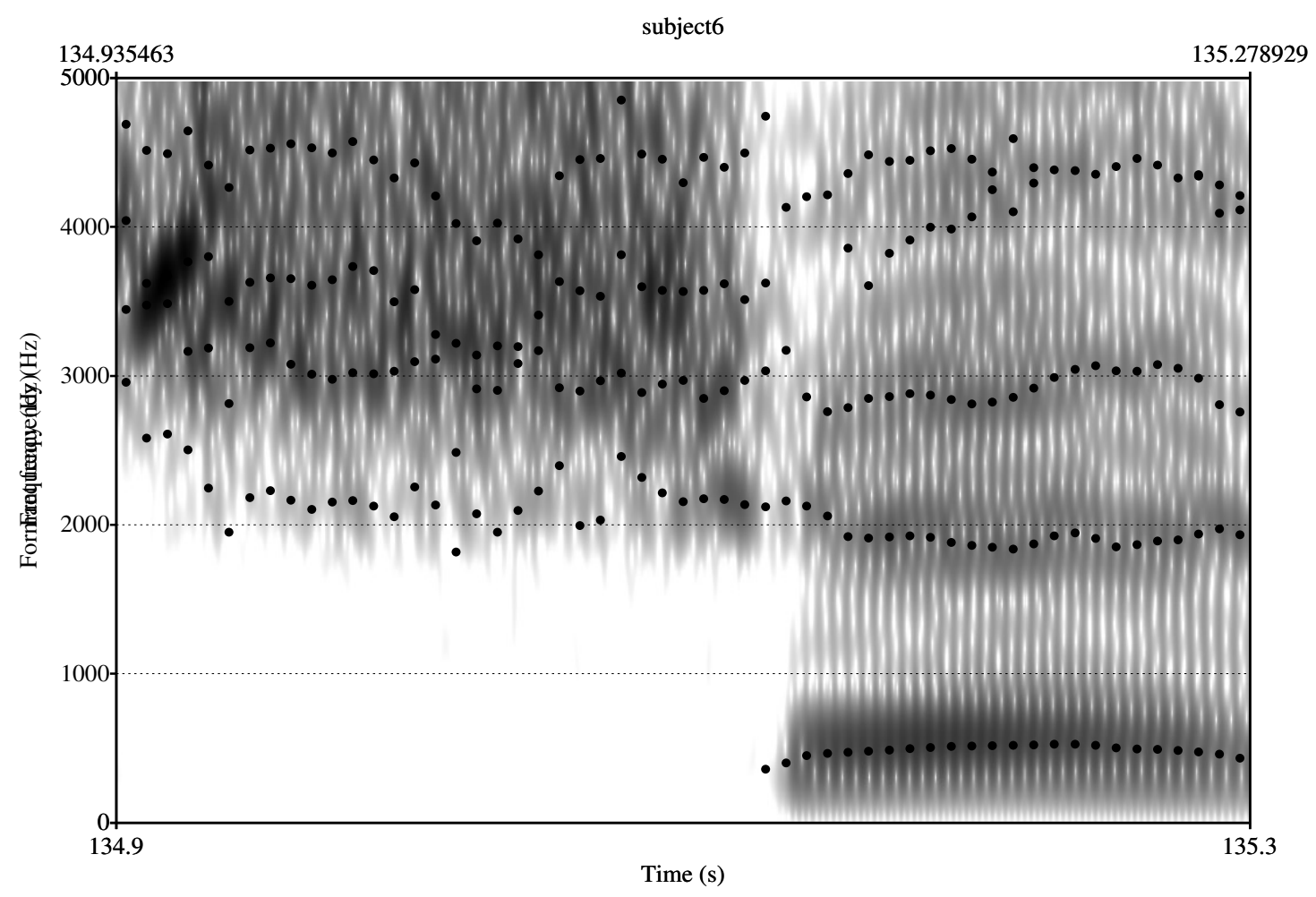

Figure 9a. Spectrogram of Subject 6's surely [' $\varnothing:]$

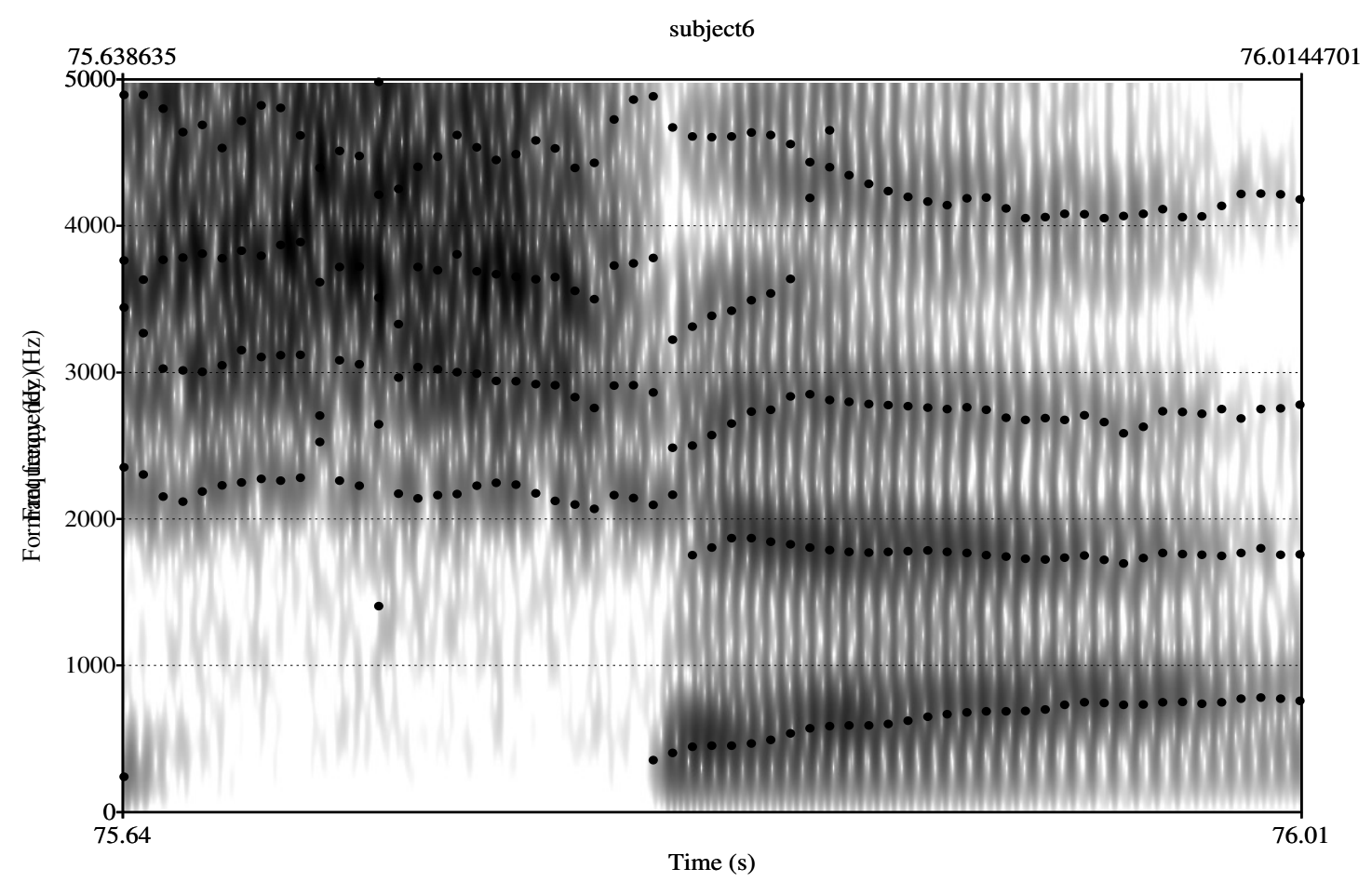

Figure 9b. Spectrogram of Subject 6's sure ['Joə] 
sure(dotted); surely(solid); NURSE (dashed)

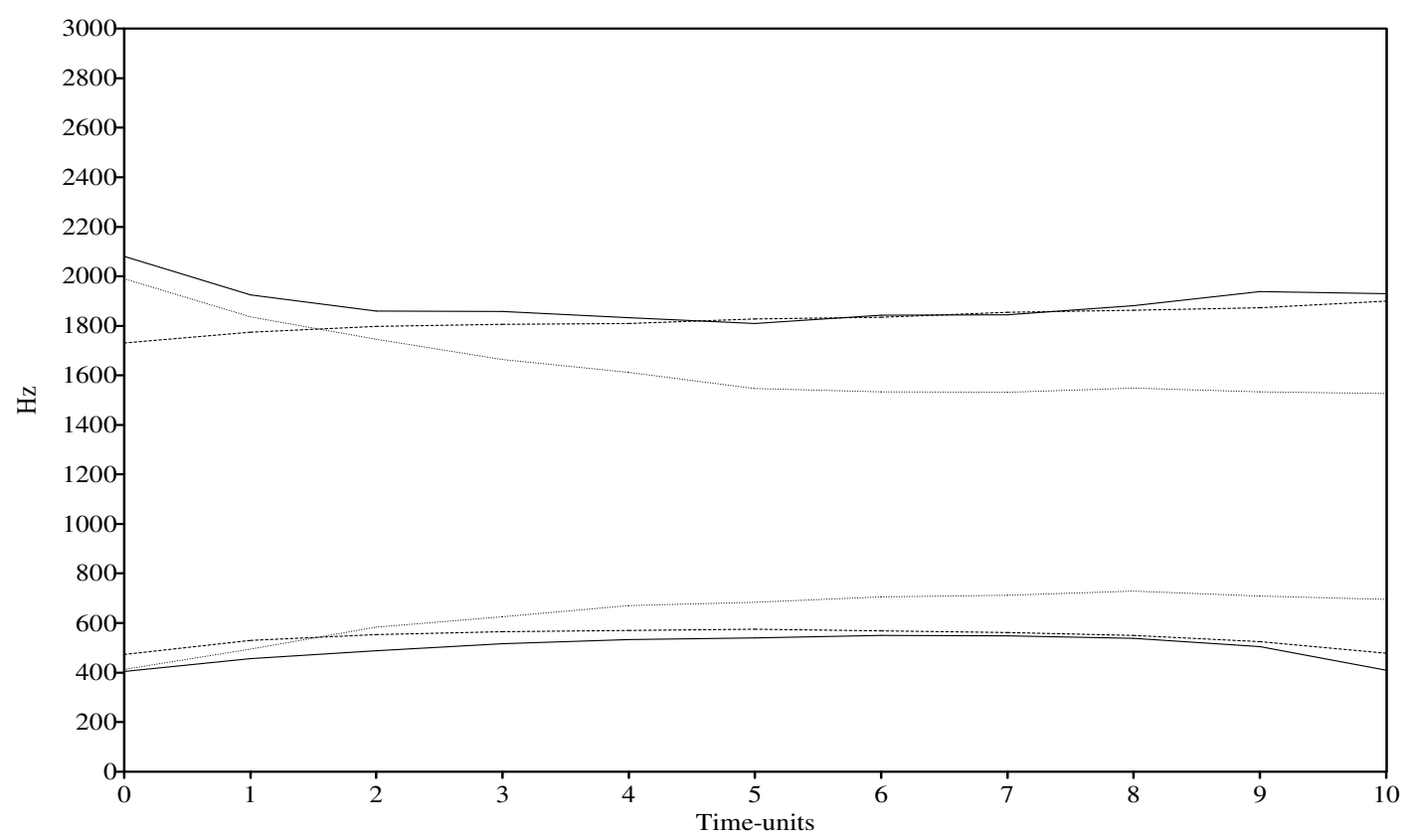

Figure 10. RR1; Average formant trajectories for surely (solid line), sure (dotted line) and NURSE (dashed line)

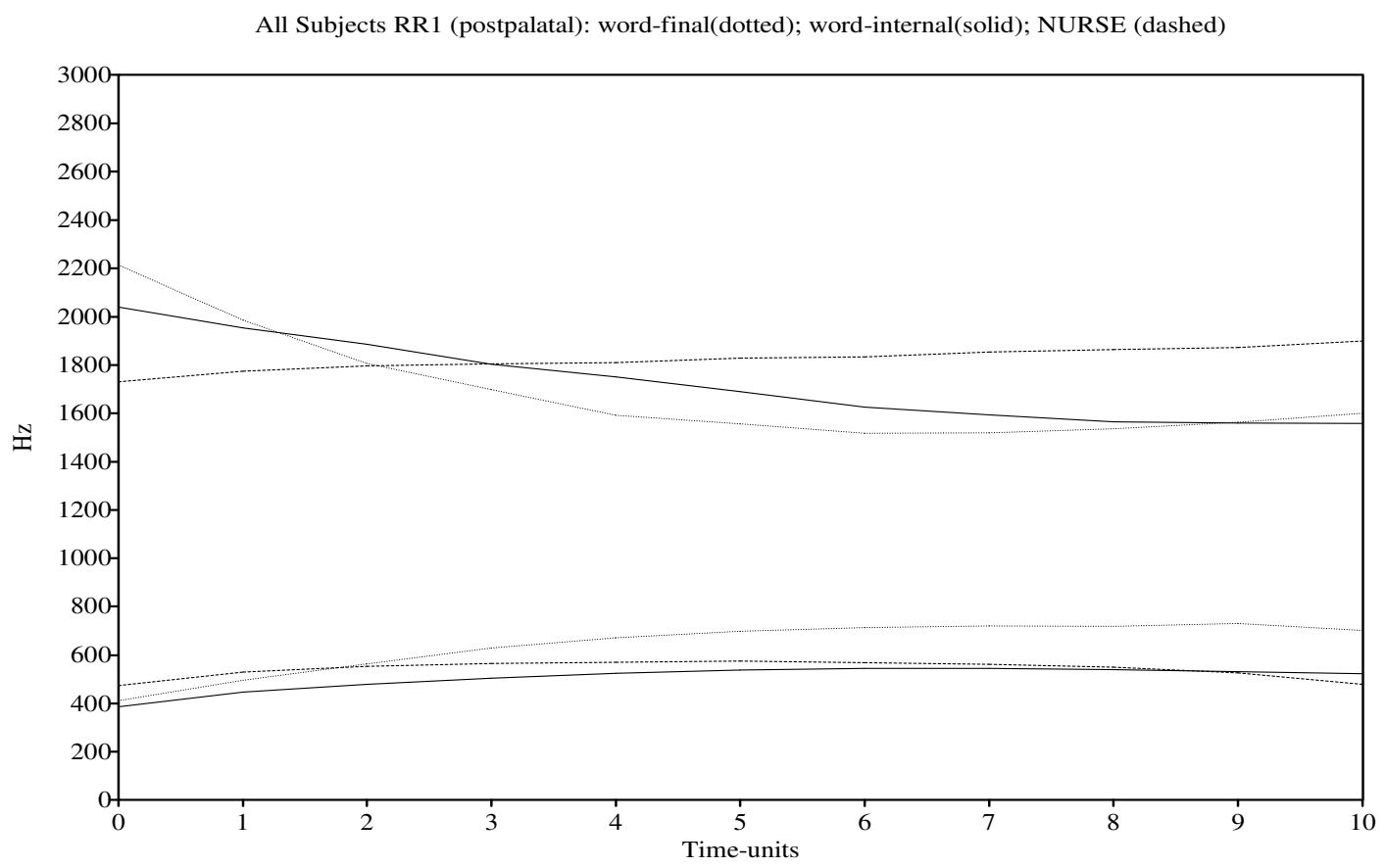

Figure 11. RR1; Average formant trajectories for post-palatal CURE in word-final position (dotted line), word-internal position (solid line) and NURSE (dashed line) 


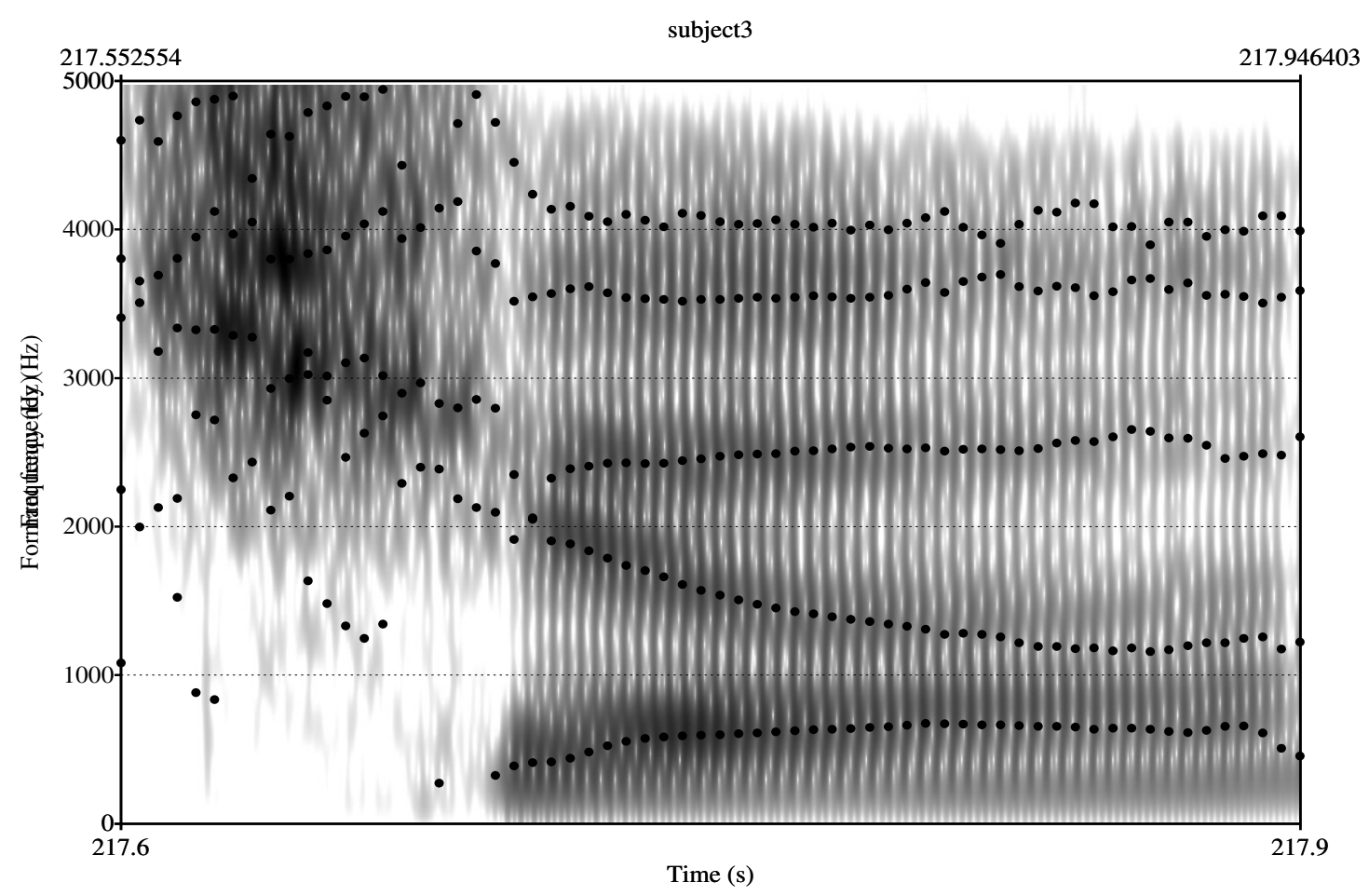

Figure 12a. Token of mature with clearly diphthongal quality

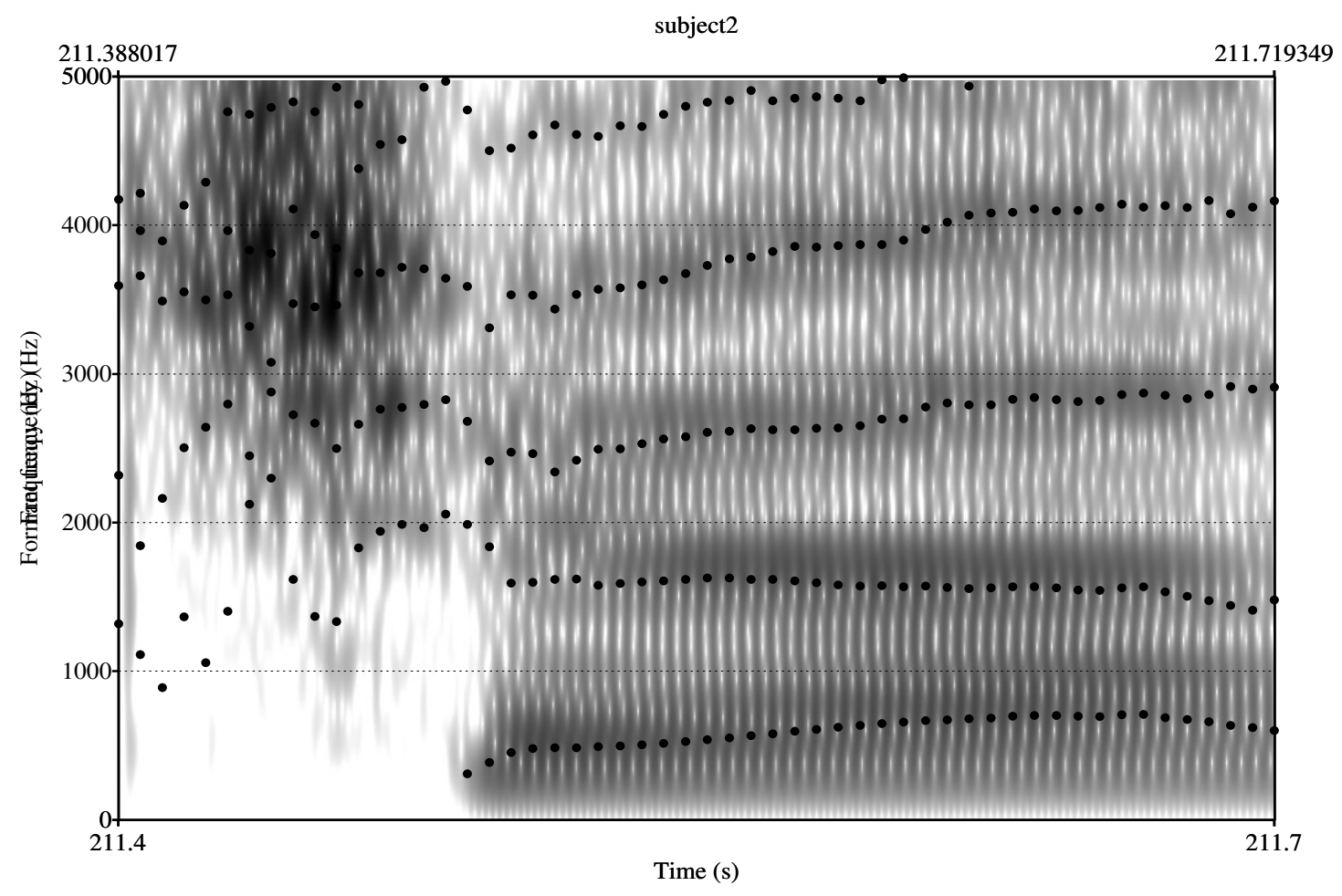

Figure 12b. Token of mature with smoothed quality 


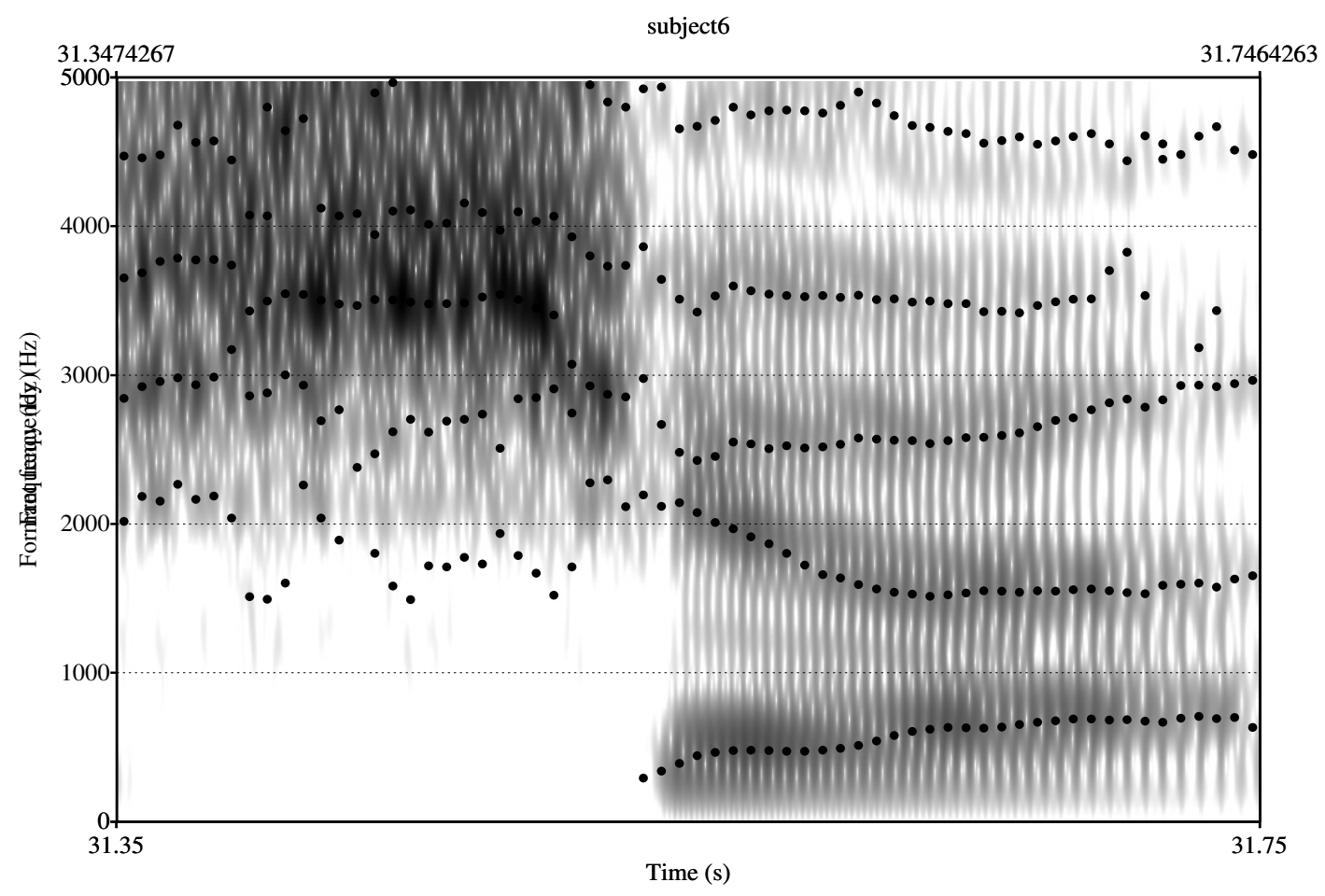

Figure 13a. Token of assure with clearly diphthongal quality

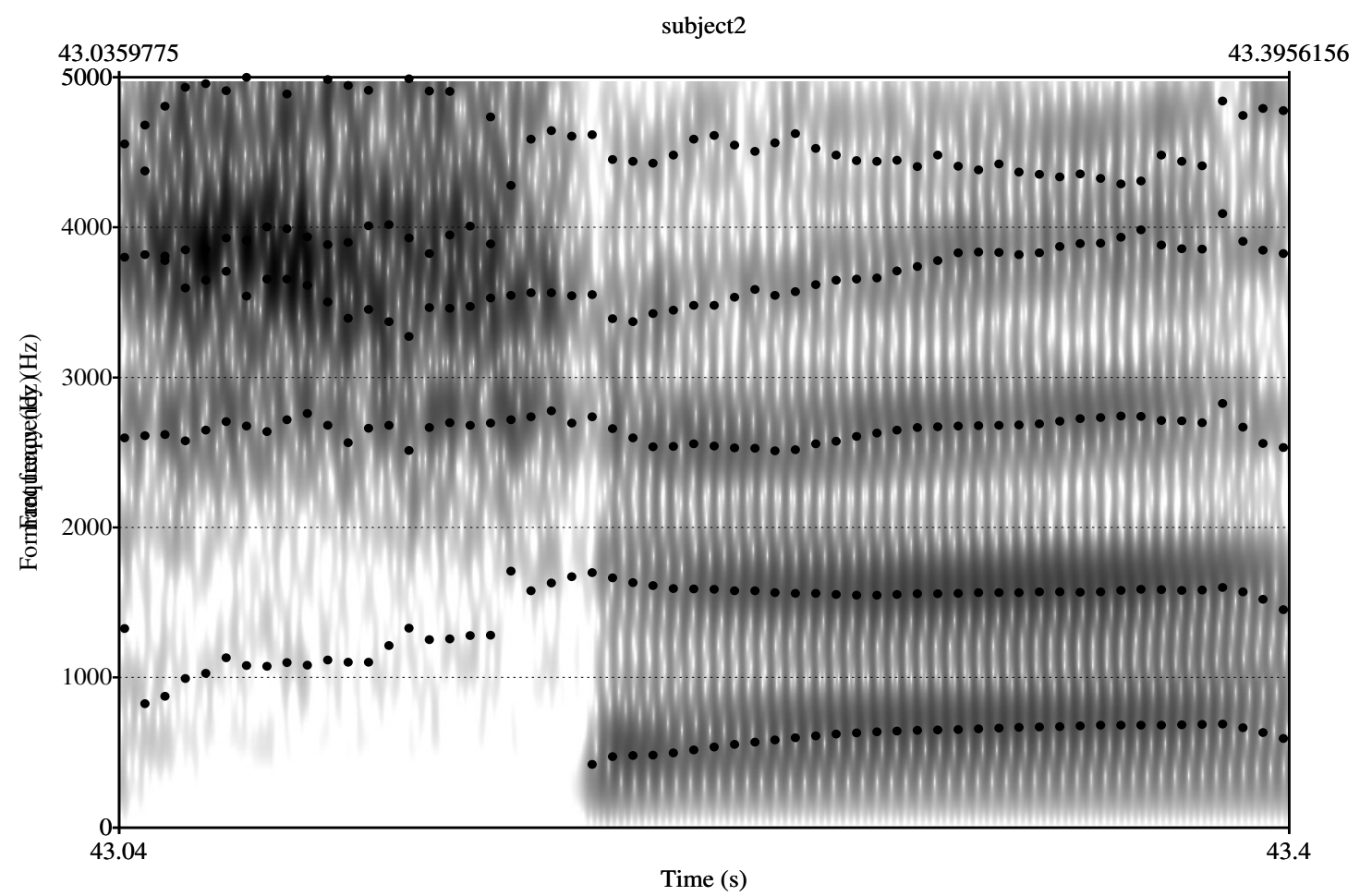

Figure 13b. Token of assure with smoothed quality 
In general, these figures provide clear support for the effect of the phonotactic position on the quality of CURE, as described in the previous section. Figure $4 \mathrm{~b}$ also provides evidence for a residual Second FORCE Merger [o:]-quality still occurring (variably) in a selected set of lexical items in SAfE. More particularly, Figures 4-9 show there is clear evidence for monophthongisation in the case of surely, while the CURE vowel in sure remains clearly diphthongal. This observation is made clearer when we average out the formant trajectories of the CURE vowel across the various surely and sure tokens, as provided in Figure 1027. While both surely and sure begin at a reasonably high front-central position (i.e. approximately $2000 \mathrm{~Hz}$, as predicted on the basis of the acoustic data for CURE in post-palatal position in Bekker (2009), and as represented in Figure 3), it is quite clear that while the CURE vowel in sure moves to a more mid-central position and is obviously diphthongal, the CURE vowel in surely does not. Figure 10 also provides average F1 and F2 formant trajectories for all the NURSE tokens in the wordlist which were produced by the six relevant subjects. The NURSElike quality of CURE in surely is clear from the overlap between the average formant trajectories of CURE in this word and those of NURSE. In essence, the results confirm that, for these speakers, surely is homophonous with Shirley.

Figure 11, on the other hand, shows the average formant trajectories of the CURE vowel in almost all of the RR1 speakers' wordlist tokens where CURE is in post-palatal position, except for Europe, neuron and mural ${ }^{28}$, and those words italicised in Table 1, i.e. CURE in nonprimary-stressed context. In particular, this includes post-palatal CURE in word-final position (obscure, assure, pure, mature) and post-palatal CURE in word-internal position (luxurious, fury, incurable, plural, curious, insurance $)^{29}$. The number of tokens in word-final position was 24 , while the number of tokens in word-internal position was $34^{30}$. While the number of speakers and tokens involved in this analysis does not allow for a statistical determination of significant difference, it was felt that the analysis summarised by Figure 11, in tandem with Figure 10, creates clear evidence of a non-categorical form of complementary distribution of CURE across phonotactic space. In Figure 11, the realisation of CURE in the relevant two phonotactic positions is again compared with wordlist NURSE and, once more, there is evidence for a greater overlap between word-internal CURE and NURSE. More particularly, the F1 of wordinternal CURE is virtually identical to NURSE, while the F2 of word-internal CURE is closer to NURSE F2 than the F2 of word-final CURE and is also more smoothed. However, the F2 of CURE overall in word-internal, post-palatal position does not overlap completely with that of NURSE (as it does in the specific case of surely), which, firstly, creates a discrepancy between the acoustic and impressionistic data and thus, secondly, requires an explanation. What follows are two possible reasons:

${ }^{27}$ The average formant trajectory for sure did not include the sure token produced by Subject 1, as represented in Figure $4 \mathrm{~b}$, given that this was an exceptional [o:]-pronunciation.

${ }^{28}$ These words were excluded because in each case it was felt that it would be particularly difficult to segment the [j]-element (which in all cases would be voiced and thus contain formants) from the preceding sonorant as well as the following vowel nucleus. In the case were the yod was preceded by a voiceless consonant (e.g. pure) or where there was a palato-alveolar fricative preceding CURE (e.g. assure), segmentation was judged to cause less problems. The words neuron and mural would have, in any case, been excluded from the acoustic analysis on the basis that, in terms of the impressionistic results contained in Table 1, these words are prone to displaying [u:] (neuron) or [于] (mural) qualities in the speech of some GenSAfE speakers, qualities which lie outside of the general pattern under analysis, i.e. [və] vs. [ø:].

${ }^{29}$ See fn. 23 for an explanation for the designation of plural as an example of CURE in post-palatal position.

${ }^{30}$ Two tokens were excluded from the acoustic analysis which formed the basis of Figure 11; one speaker misinterpreted fury as furry, while the formants of one token of incurable were not clear enough for formant analysis. 
1. Mis-transcriptions on an impressionistic level (i.e. there are more diphthongal variants of CURE in word-internal, post-palatal position than reflected in Table 1);

2. One possible interpretation of the results collectively contained in Figures 4-10 and 11 is that while in some cases (e.g. surely) a NURSE-like quality has been phonologised (i.e. [ø:] is the target) ${ }^{31}$, the reason for the lack of diphthongal movement in other cases is that the word-internal position of the vowel leads to undershoot. Put differently, the fact that word-internal syllables are generally shorter than word-final ones means that there is less chance that any particular glide target will be reached, e.g. the [ə] of [ชə]. On this interpretation, the smoothing of CURE in word-internal position is simply a mechanical, predictable and purely phonetic consequence of its phonotactic position in the word. On this basis, the target is still [0ə] and not [ $\varnothing:]$ and the degree of monophthongisation is, as a result, highly variable.

Furthermore, the distribution of [ซə] vs. [ $\varnothing:$ ] qualities is made additionally complex by the fact that NURSE-like qualities also appear in word-final position in the SAfE data contained in Table 1 (specifically in pure, insecure and cure). In some cases, e.g. in pure, a NURSE-like quality might, in fact, have been subject to phonologisation. In many cases, however, the use of smoothed, NURSE-like qualities is highly variable, pointing again to the fact that the difference between the two phonotactic positions of CURE, as represented in Figure 11, reflects a tendency rather than an exceptionless form of complementary distribution. Figures 12 and 13 provide evidence for this assertion in the form of data from the acoustic record of the tokens mature and assure, both transcribed categorically as diphthongal in Table 1 . In each case, the (a) figure provides an example of the relevant token with a clearly diphthongal variant of CURE, while the (b) figure provides an example of the relevant token with more smoothed formant trajectories.

In conclusion, the results of sections 5.1 and 5.2 provide a complex picture, but also compelling evidence for the tendency of CURE to become monophthongised to [ $\varnothing:]$ in word-internal, postpalatal position, while in word-final, post-palatal position the tendency is for a diphthongal variant (narrowly [Yə]) to prevail. It should be stressed, however, that there are a number of exceptions to this pattern:

1. The occasional use of [u:] or [ซ] qualities in a couple of words (e.g. neuron and mural) where [ $\varnothing:]$ would be expected in terms of the prevailing pattern;

2. While in some cases there appears to be a categorical use of [ $\varnothing:]$ in word-internal, postpalatal position (e.g. surely) and thus evidence for phonologisation to [ø:], in other cases there would appear to be variable degrees of smoothing to [ø:], accounting for the fact that the F2 of CURE overall in word-internal, post-palatal position, while more smoothed than its counterpart in word-final position, does not overlap with the F2 in

\footnotetext{
${ }^{31}$ When phonologisation occurs, what was once a mechanical, phonetic process becomes assimilated into the grammar, probably through misperceptions on the part of new language-learners (i.e. children), and in the process gains independence from its earlier mechanical constraints. See, for example, Barnes (2006) for a fuller discussion. The distinction between unphonologised (i.e. purely phonetic) and phonologised processes can also be usefully recast as the distinction between accommodatory and non-accommodatory allophony as described by Wells (1982:41-44). As pointed out by Cho and McQueen (2008:240), the difference between these two kinds of allophony is where, in the first instance, the listener relies on "acoustic remnants of the speaker's intention that might still be present in the speech signal" while in the second instance the speaker has to draw on phonological or lexical knowledge.
} 
NURSE, as shown in Figure 11. Such variability is, in all likelihood, the result of the purely phonetic effect of glide undershoot in word-internal position;

3. The use of [ $\varnothing$ :]-like (i.e. smoothed) qualities in word-final position, e.g. pure in Table 1 and mature and assure in Figures 12(b) and 13(b) respectively, and

4. The exceptional use of a Second FORCE Merger-based [o:]-quality, e.g. sure in Figure 4(b).

\subsection{RR2: Impressionistic results}

As mentioned in the previous section, RR2 was focused more on CURE in non-post-palatal position and also drew data from two generations of GenSAfE speakers. Table 2 provides impressionistic data for the younger five speakers, while Table 3 provides impressionistic data for the older five speakers.

Table 2. Information relating to CURE words in Recording Round 2 (RR2): Younger informants

\begin{tabular}{|c|c|c|c|c|}
\hline Word & CF/RD & OED & LPD & SafE \\
\hline tour & $\mathrm{CF}$ & 'tuə 'tuər & 'tvə/'to: 'tv ${ }^{\partial} \mathrm{r}$ & 'too \\
\hline plural & $\mathrm{CF}$ & 'plひə/'plっ: 'plひ & 'plひə/'plっ: 'plひ & plø: \\
\hline lurid & $\mathrm{CF}$ & '1(j)ขә & 'ljuə/'lvə/'lj3:/'ljo: 'lor & $1 \varnothing:$ \\
\hline rural & $\mathrm{CF}$ & 'roə 'ror & 'roə 'ror & ru: \\
\hline poor & $\mathrm{CF}$ & $\begin{array}{l}\text { 'p⿰ə/'po: } \\
\text { 'pv(ə)r/'po(ə)r }\end{array}$ & 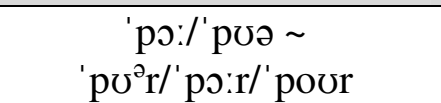 & 'poə \\
\hline allure & $\mathrm{CF}$ & 'l(j)шə 'lu(ə)r & 'lvə/'ljuə/'ljo: 'lơr & 'lбә/'lø:(2) \\
\hline spoor & $\mathrm{CF}$ & 'spuə 'spuər & $\begin{array}{c}\text { 'spuə/'spo: } \\
\text { 'spo } \mathrm{r} / \text { /'spo:r/ spour }\end{array}$ & 'spəə \\
\hline moor & $\mathrm{CF}$ & 'mvə/'mo: 'mv(ə)r & 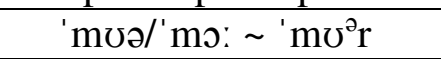 & 'moə \\
\hline tourist & $\mathrm{CF}$ & 'tur & 'toə/'to: 'tor & 'tø:/' t兀ə(1) \\
\hline tour & $\mathrm{RD}$ & 'tøə 'tuər & 'toə/'to: 'to ${ }^{\partial} \mathrm{r}$ & 'toə \\
\hline spoor & $\mathrm{RD}$ & 'spøə 'spøər & 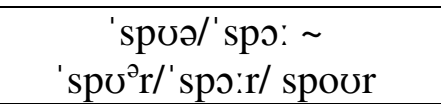 & 'spoə \\
\hline rural & $\mathrm{RD}$ & 'roə 'ror & 'roə 'ror & ru: \\
\hline moor & $\mathrm{RD}$ & 'mvə/'mo: 'mv(ə)r & 'mvə/'mo: 'mvr & moə \\
\hline Truro & RD & N/A & 'troə 'trur & 'tru: \\
\hline
\end{tabular}

Table 3. Information relating to CURE words in Recording Round 2 (RR2): Older informants

\begin{tabular}{|c|c|c|c|c|}
\hline Word & CF/RD & OED & LPD & SafE \\
\hline tour & $\mathrm{CF}$ & 'tuə 'tuər & 'toə/'to: 'to ${ }^{\ominus} \mathrm{r}$ & 'tuə \\
\hline plural & $\mathrm{CF}$ & 'pløə/'plo: 'plø & 'pløə/'plっ: 'plひ & $\begin{array}{c}\text { 'plø:/'pløə(1)/ } \\
\text { 'plu:(1) }\end{array}$ \\
\hline lurid & $\mathrm{CF}$ & '1(j)ชə & 'ljuə/'løə/'lj3:/'ljo: 'lor & 'ljø:/'lø:(1)/'lu:(1) \\
\hline rural & $\mathrm{CF}$ & 'roo 'ror & 'roə ' ror & 'ru:/'roə(1) \\
\hline poor & $\mathrm{CF}$ & $\begin{array}{c}\text { 'pvə/'po: } \\
\text { 'pv(ə)r/'po(ә)r }\end{array}$ & 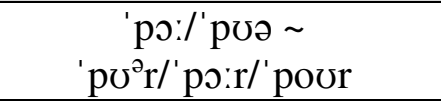 & 'рбә \\
\hline allure & $\mathrm{CF}$ & 'l(j)və 'lu(ə)r & 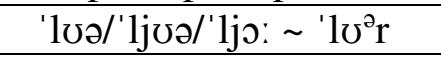 & 'ljoə/' lø:(1) \\
\hline
\end{tabular}




\begin{tabular}{|c|c|c|c|c|}
\hline spoor & $\mathrm{CF}$ & 'spøə 'spøər & $\begin{array}{c}\text { 'spoə/'spo: } \\
\text { 'spoər/'spo:r/ spoor }\end{array}$ & ' spøə \\
\hline moor & $\mathrm{CF}$ & 'mvə/'mo: 'mv(ə)r & 'mvə/'mo: 'mo & 'muə \\
\hline tourist & $\mathrm{CF}$ & 'toə & 'toə/'to: 'tor & 'tø:/'toə(2) \\
\hline tour & $\mathrm{RD}$ & 'toə 'tuər & 'toə/'to: 't $\sigma^{\ominus} \mathrm{r}$ & 'tชว \\
\hline spoor & $\mathrm{RD}$ & 'spøə 'spøər & 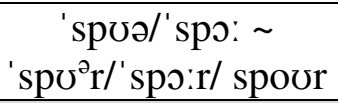 & 'spuə \\
\hline rural & $\mathrm{RD}$ & 'roə 'ror & 'roə 'ror & 'ru:/'rø:(1) \\
\hline moor & $\mathrm{RD}$ & 'muə/'mo: 'mu(ə)r & 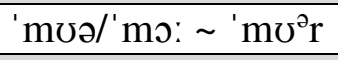 & 'mขə \\
\hline Truro & $\mathrm{RD}$ & N/A & 'troə 'tror & 'tru:/' trø:(2) \\
\hline
\end{tabular}

Any differences between the two generations based on such a limited amount of data should, of course, be interpreted with a high degree of caution. However, it is suggestive that the older subjects seem to have a higher degree of variability with respect to CURE in word-internal position (see plural, lurid, rural (x2), tourist and Truro). In the case of the younger speakers, all but one case ${ }^{32}$ of CURE in word-internal position is monophthongal (and categorically either [ø:] or [u:]), while in the case of the older speakers there appears to be a high degree of variability between the monophthongal and diphthongal variants, on the one hand, and the two monophthongal variants on the other. This suggests that GenSAfE might be in the process of ever-increasing stabilisation in terms of word-internal positional realisations of CURE. It should be stressed, however, that these suggestions may be used as hypotheses for future research and are not considered to be firm results of the current analysis.

Importantly, RR2 was focused on testing whether or not there was evidence for the development of NURSE-like realisations of CURE in non-post-palatal position. The impressionistic data seems to indicate that a distribution similar to that of CURE in post-palatal position occurs in non-post-palatal position as well; in other words, there is a tendency towards monophthongal realisations in word-internal position and fully-diphthongal [ひə]-realisations in word-final position. As we shall see, however, the acoustic evidence somewhat contradicts the impressionistic evidence, i.e. while there is indeed monophthongisation (smoothing) of CURE in word-internal, non-post-palatal position, the resultant quality is different to that created in word-internal, post-palatal position.

\subsection{RR2: Acoustic evidence}

In an similar fashion to Figure 11, Figure 14 provides average formant trajectories for CURE in the two relevant phonotactic positions, based, on the one hand, on the wordlist productions of the 10 tourist tokens and, on the other hand, the wordlist tokens of tour, poor, moor and spoor by the same 10 subjects (38 tokens in total ${ }^{33}$ ). Again, the wordlist productions of the NURSE vowel, by the relevant subjects, were used as a basis for comparison (100 tokens). Unfortunately, there was not much data available for possible NURSE-like CURE in non-postpalatal, word-internal position. Firstly, this was because, in the case of rural and Truro, the majority of monophthongal pronunciations were clearly GOOSE-like (with only one [ $\varnothing$ :] in the impressionistic data). Secondly, a number of words (plural and lurid in particular) which were originally included in the stimulus material in order to elicit CURE in non-post-palatal position,

\footnotetext{
${ }^{32}$ I.e. tourist.

${ }^{33}$ One subject's spoor and moor tokens were not suitable for formant analysis.
} 
had to be rejected since it was only realised after data collection had taken place, that the /1/ which precedes CURE would naturally take on a palatal quality, given the clear-dark allophony of / $1 /$ in SAfE, as in RP. Consequently, these words had to be excluded from the analysis of CURE in non-post-palatal, word-internal position and only tourist was left.

In Figure 14, and with respect to F1, there is a clear diphthongal movement from a higher- to a mid-position in the case of CURE in word-final position; the F2 trajectory of this positional variant of CURE shows a similar diphthongal movement from a back to a centralised position, as represented in Figure 3, which is in alignment with the results contained in Bekker (2009). This represents the canonical CURE pronunciation, i.e. narrowly [0ə]: the lack of a preceding palatal or palato-alveolar sound means that the diphthong is not conditioned to proceed from a centralised-to-front position.

With respect to non-post-palatal CURE in word-internal position (i.e. tourist), there is a clear difference: the vowel is not lowered to a mid-central position as is the case with CURE in wordfinal position and, in fact, closely follows the F1 trajectory of NURSE. The F2 trajectory is a little more difficult to interpret. Firstly, in terms of real $\mathrm{Hz}$ values, it approximates the NURSE values more closely than CURE in word-final position for most of the trajectory and, while it is demonstrably smoother than CURE in word-final position, it is also clearly further retracted in phonetic space than NURSE.

One possible reason for the fronter (higher F2) values for CURE in word-internal position, as represented in Figure 14, is the fact that the one word on which the relevant representation was based (i.e. tourist) contains an anterior coronal [t]-sound preceding the CURE vowel. As is well-known, anterior coronal sounds commonly condition fronting of adjacent vowels. To control for this effect, and on a similar basis to the prior analysis of sure vs. surely, the formant trajectories of the two near-identical tokens tour and tourist were compared. Figure 15 provides the relevant results and there are two main observations to make here. Firstly, the F1 formant trajectory of tour still shows far greater diphthongal movement in comparison to tourist. Secondly, in the case of tour, while there is evidence of the fronting effect of the preceding coronal (as is clear if one compares the F2 formant trajectory of tour in Figure 15 with the overall average F2 formant trajectory of non-post-palatal CURE in word-final position as contained in Figure 14), resulting in the tour F2 formant trajectory being even closer to NURSE for most of its duration, it is still clearly diphthongal and does not show the same degree of smoothing as is the case of the F2 formant trajectory of non-post-palatal CURE in word-internal position (i.e. tourist). However, what is clear is that the conditioning effect of the preceding coronal has a similar effect on the CURE vowel in both tourist and tour. This fronting effect is, of course, a clear case of accommodatory allophony, as is, by all accounts, the differential effect of phonotactic position (i.e. word-internal vs. word-final). Again, however, this distribution between clearly diphthongal CURE in word-final position vs. smoothed CURE in word-internal position does not appear to be a categorical one. Figures 16 and 17 (analogous to Figures 12 and 13) provide clearly diphthongal vs. more clearly monophthongal realisations for the tour and tourist tokens respectively. 
All Subjects RR2 (nonpostpalatal): word-final(dotted); word-internal(solid); NURSE (dashed)

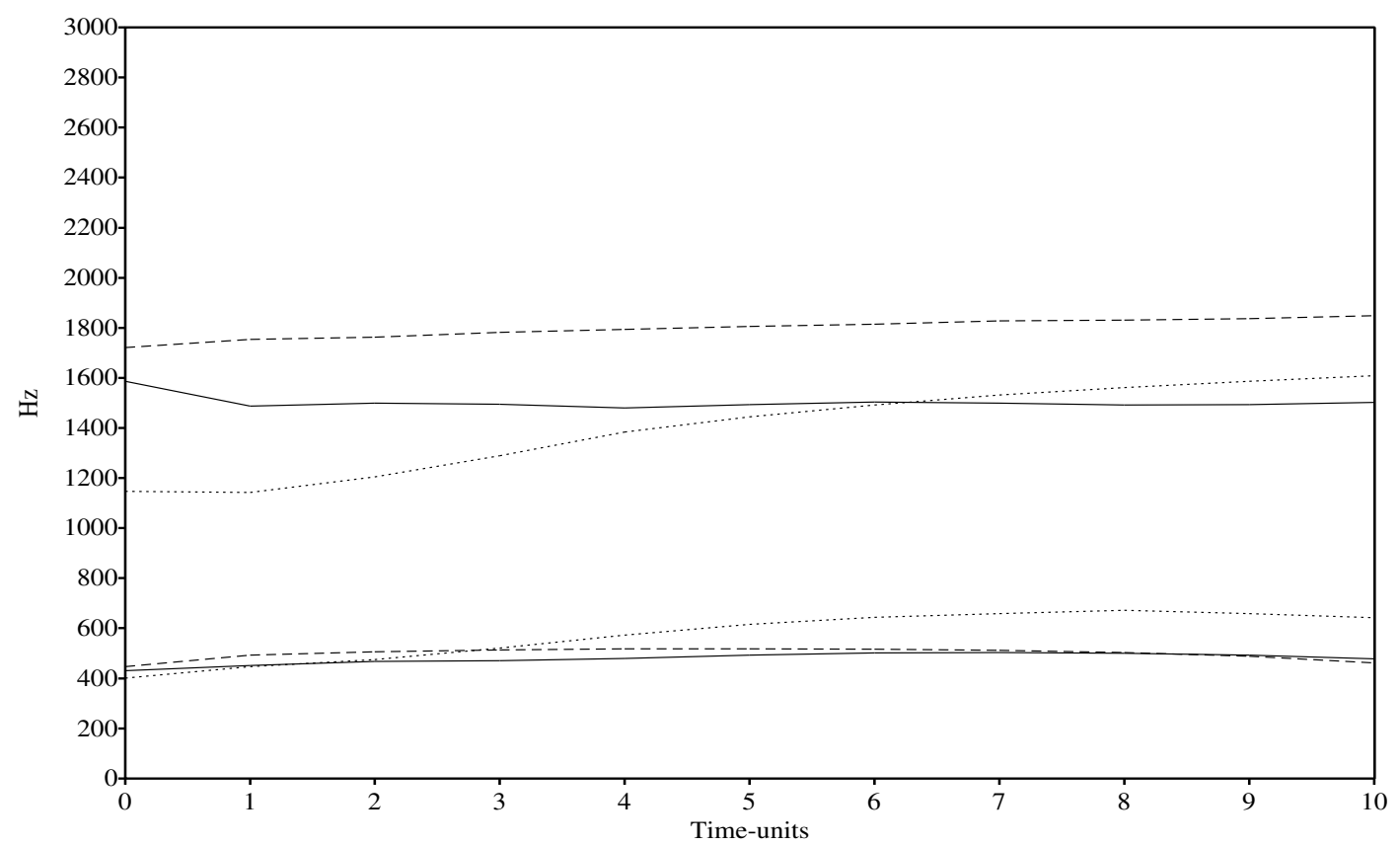

Figure 14. RR2; Average formant trajectories for non-post-palatal CURE in word-final position (dotted line), word-internal position (solid line) and NURSE (dashed line)

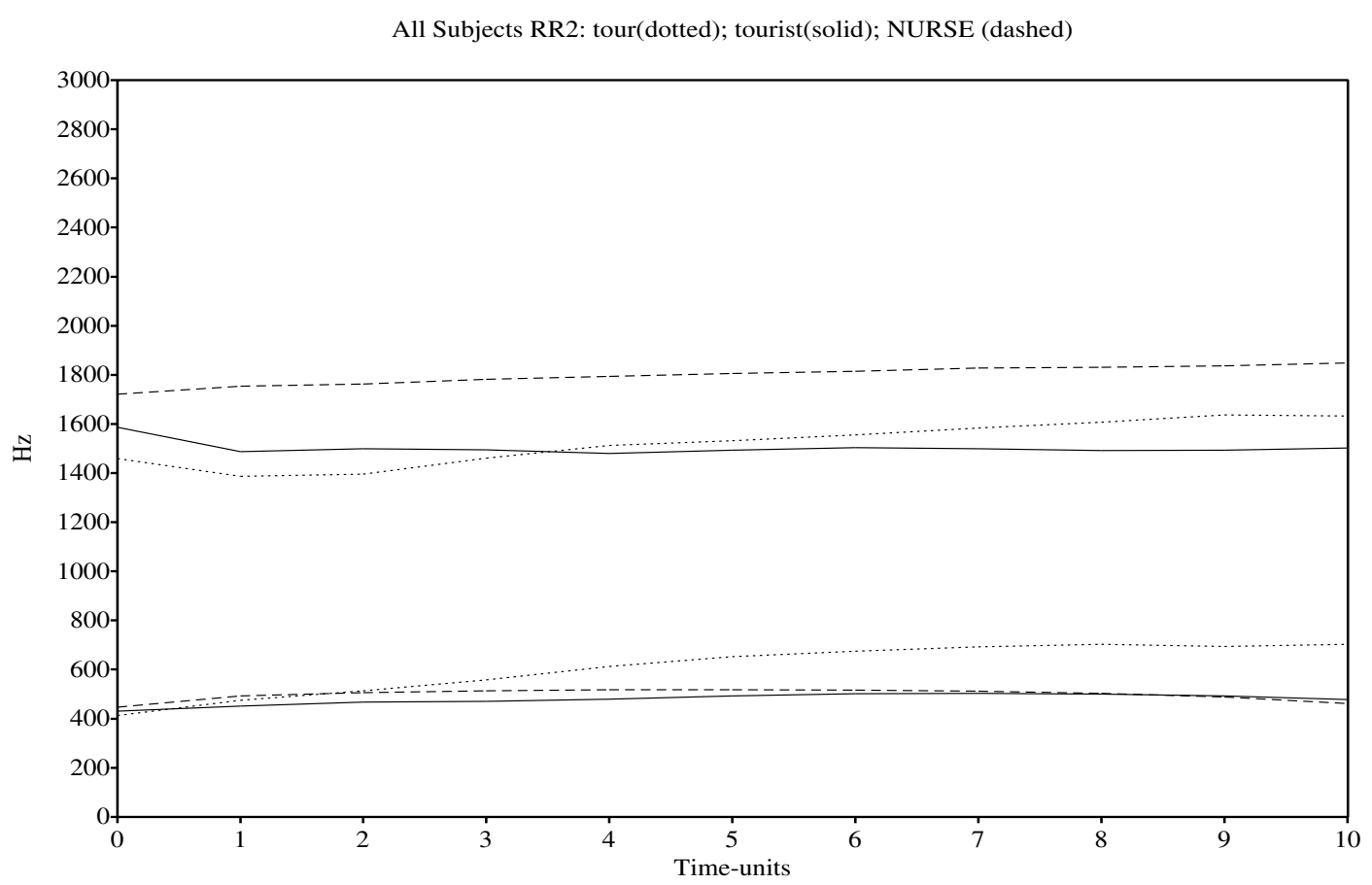

Figure 15. RR2; Average formant trajectories for tourist (solid line), tour (dotted line) and NURSE (dashed line) 


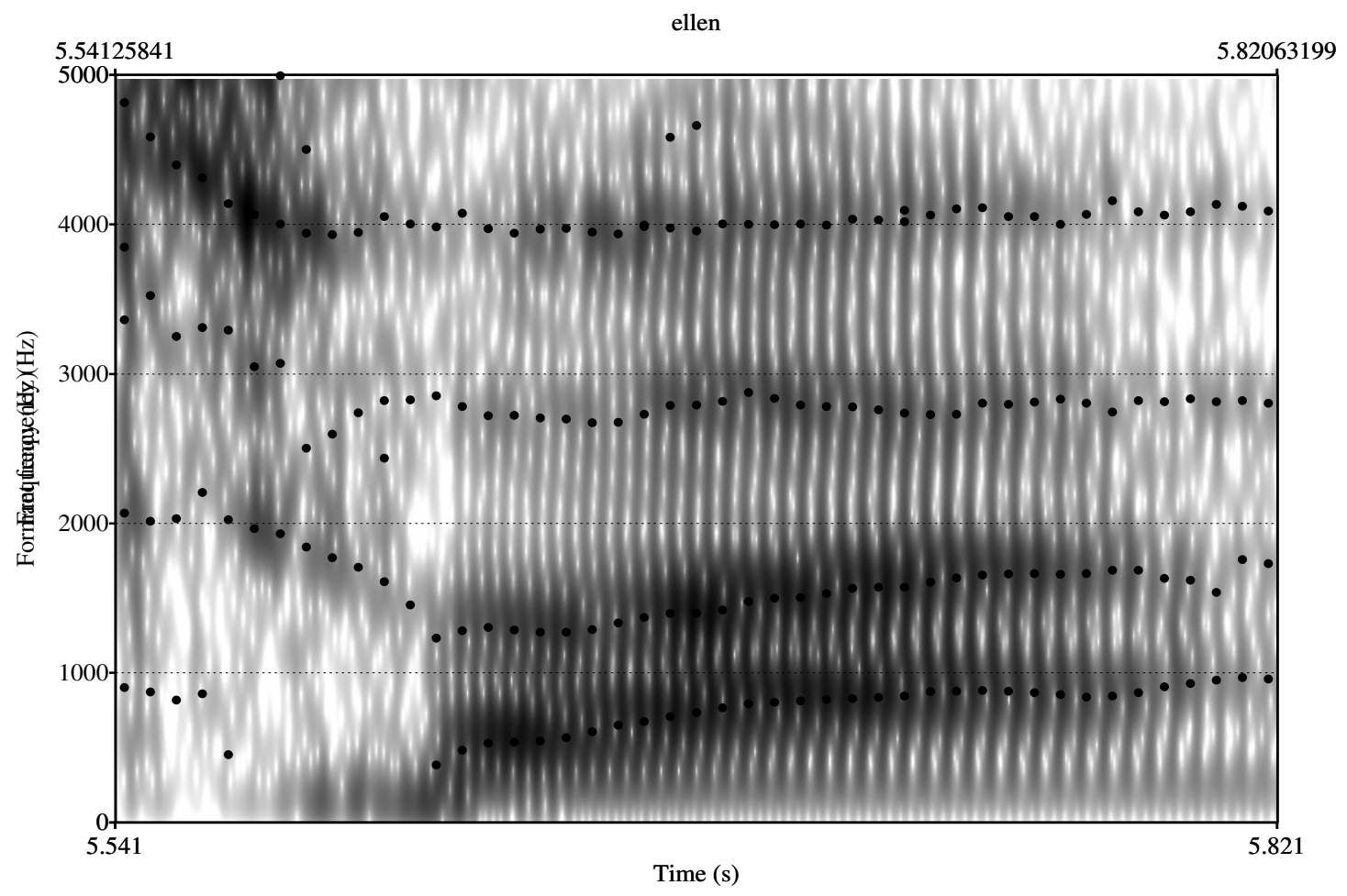

Figure 16a. Token of tour with diphthongal quality

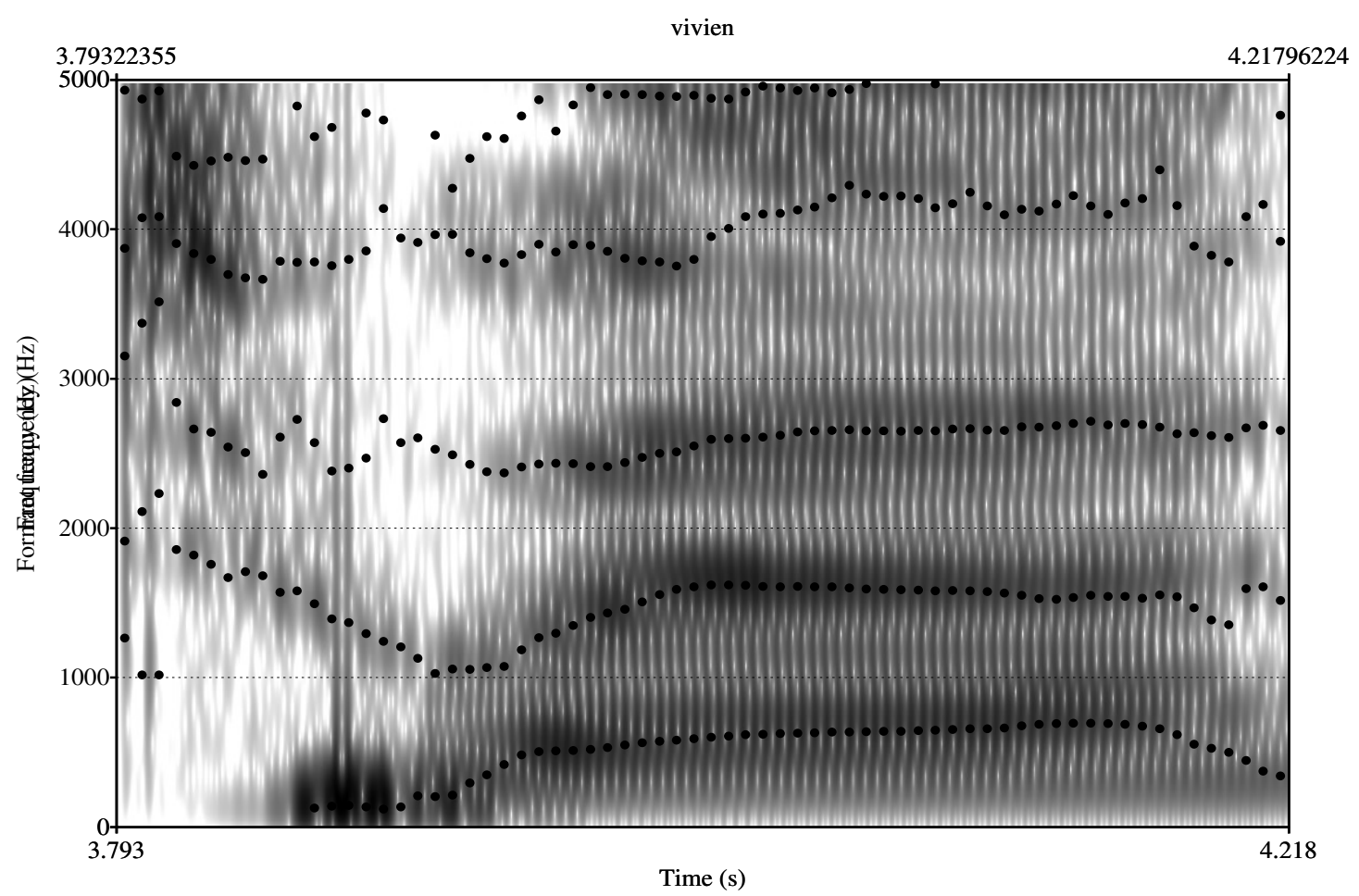

Figure 16b. Token of tour with a more monophthongal quality 


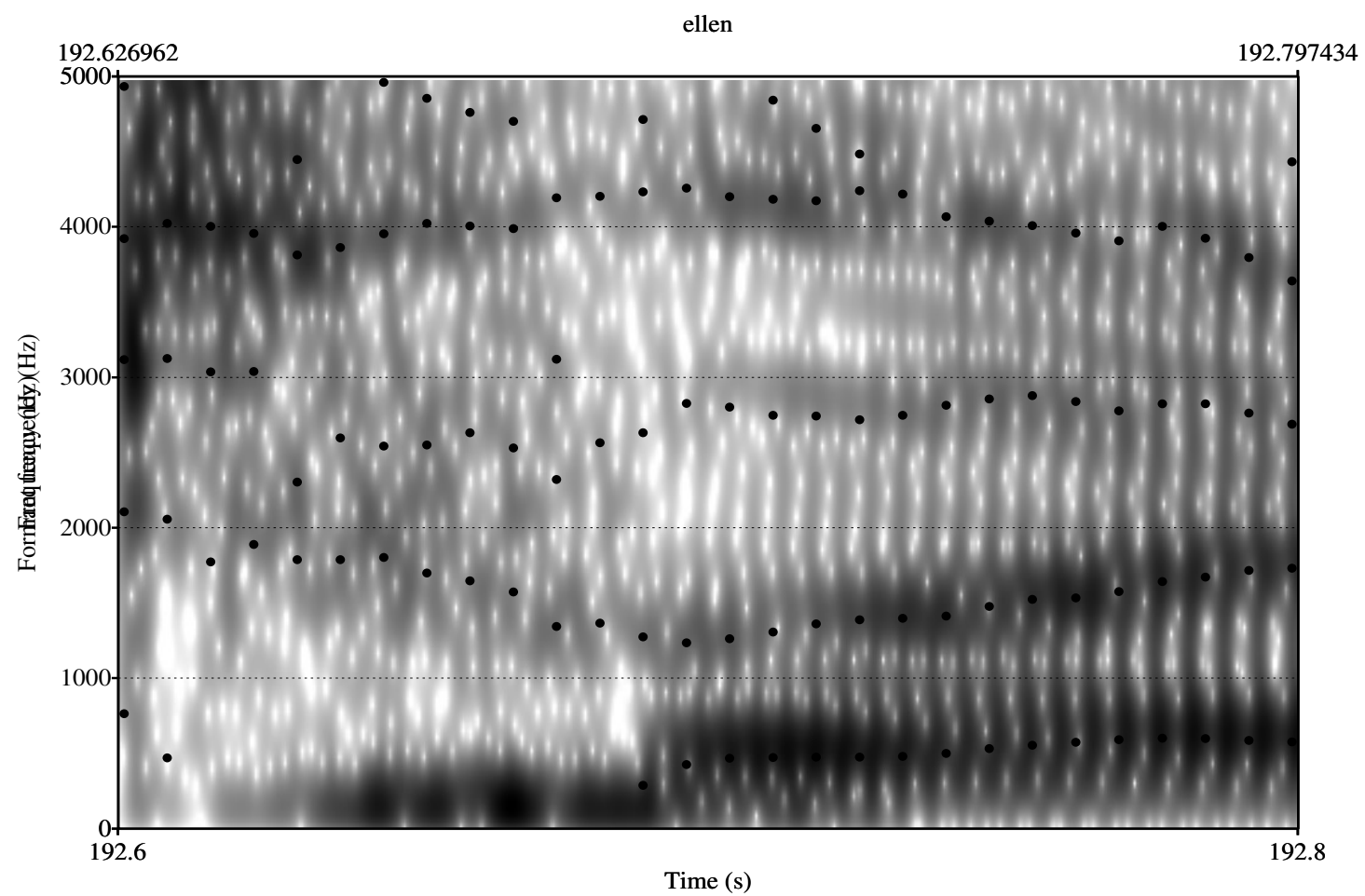

Figure 17a. Token of tourist with diphthongal quality

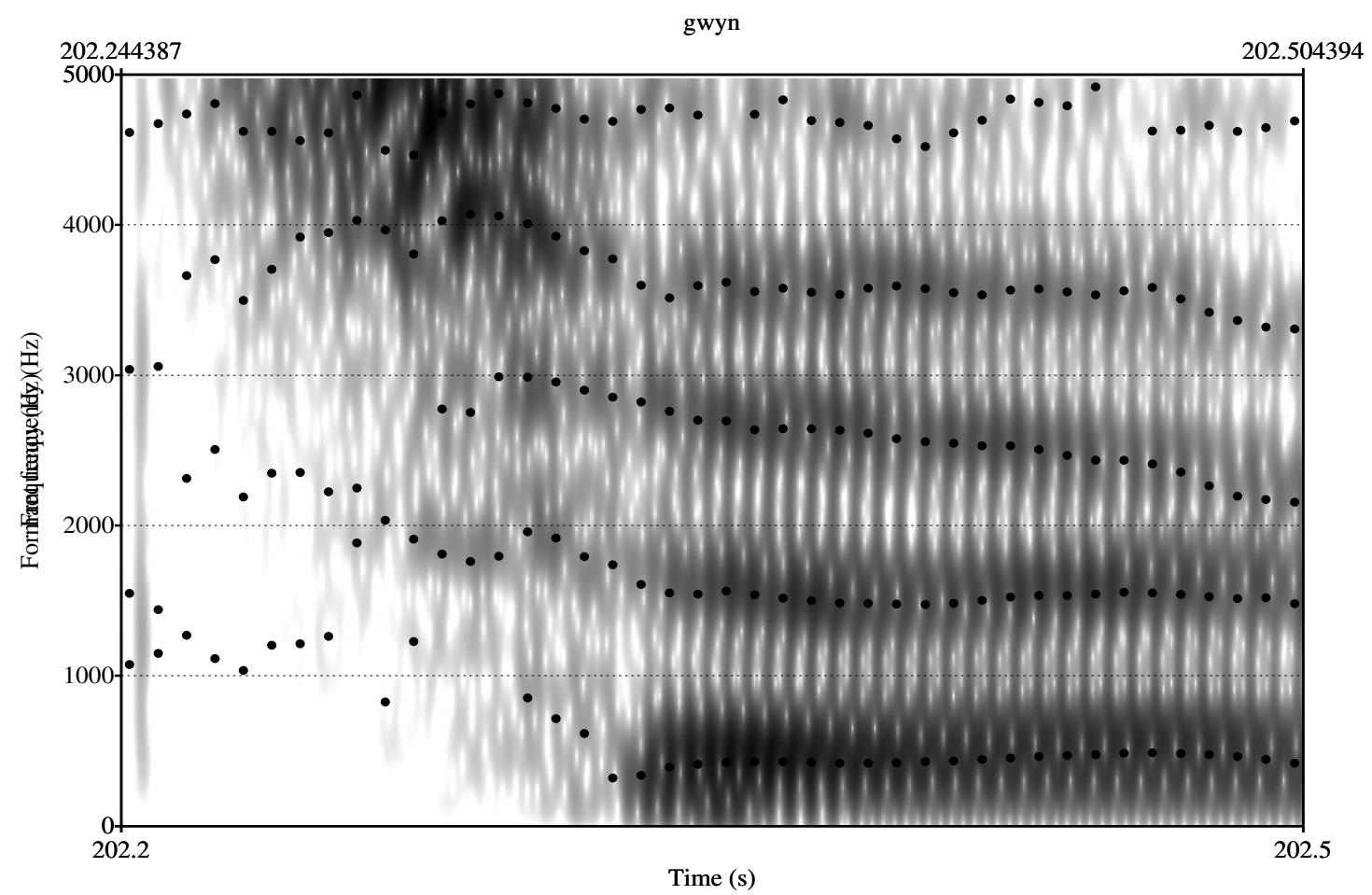

Figure 17b. Token of tourist with a more monophthongal quality 
An alternative and more elegant hypothesis for the results represented in Figures 14 and 15 is that what we are essentially dealing with here is monophthongisation to GOOSE, and that the impressionistic values provided in this regard, and as contained in Tables 2 and 3, are mistranscriptions, e.g. it should be [tu:.Jəst] and not [tø:.əst]. Given the occurrence of clear (and presumably phonologised) GOOSE-like values in non-post-palatal, word-internal position (e.g. rural, Truro), this would be useful in the sense of isolating GOOSE-like values to non-postpalatal, word-internal position, while NURSE-like values are characteristic of the wordinternal, post-palatal position. As such, a comparison between the tourist token and the GOOSE vowels of the same subjects would have been useful. Unfortunately, GOOSE values from the wordlist were not collected for the purposes of this study, but it was felt that the use of Bekker's (2009) results for GOOSE would be a fair basis for comparison. The results from Bekker (2009) clearly show a high-fronted GOOSE vowel even in non-coronal contexts, with the temporal mid-point F2 value being $2116 \mathrm{~Hz}$ for the relevant subjects, a position higher than the NURSE vowel at $1930 \mathrm{~Hz}$. The GOOSE value in Bekker (2009) was also averaged out across the tokens who'd, boot, food, wounded and cute (i.e. including GOOSE after back velar/w/); GOOSE after a coronal like / $t$ / (i.e. equivalent to tourist) would no doubt have displayed an even fronter value. It would appear, therefore, that the NURSE vowel remains, in terms of both F1 and F2 qualities, the closest long monophthongal vowel to the vowel quality of CURE in tourist and thus accounts for the transcription of tourist as [tø:Jəst] in Tables 3 and 4. A narrower transcription would be along the lines of [tu:Jəst], i.e. with a clearly centralised long monophthong further back than both GOOSE or NURSE.

\section{Discussion and conclusion}

The data provided in Bekker (2009), and represented in Figures 2 and 3 of this article, clearly shows that CURE in SAfE (and presumably any other non-Second FORCE Merger accents of English) has two main allophones, namely post-palatal and non-post-palatal. The data collected specifically for the purposes of the current article shows that the post-palatal/non-post-palatal distinction interacts in interesting ways with another form of distribution, namely word-internal vs. word-final. Although the effect is more statistical than categorical, it is clear from the results of this study that CURE in word-internal position (in both post-palatal and non-post-palatal contexts) is subject to smoothing and monophthongisation. In contrast, in the case of CURE in word-final position there is a tendency for CURE to retain its fully diphthongal status. The following list provides a summary of the results of the preceding analysis in terms of the differing realisations of CURE as used in the GenSAfE analysed for the purposes of the current research:

1. Non-post-palatal, word-final: [ซə]

2. Non-post-palatal, word-internal: [u:]

3. Post-palatal, word-final: [yə]

4. Post-palatal, word-internal: [ø:]

5. Phonologised versions of GOOSE-like (e.g. mural) and NURSE-like (e.g. pure) values which contradict the abovementioned distribution

6. Residual Second FORCE Merger [o:]-values

As such, (1) is the canonical (or unmarked) realisation of CURE, while (2-4) are due to purely phonetic pressures and are highly variable, particularly in terms of the effect of phonotactic 
position (word-internal vs. word-final). This variability is then further complicated by the presence of (5) and (6).

Some speculation as to the sources of this distribution is warranted. One obvious reason for the word-internal vs. word-final distribution is the well-attested fact that vowels in word-internal position are likely to undergo the purely mechanical effect of undershoot, i.e. the less time available for target production means, quite simply, that some of the targets are not reached. In the case of CURE in word-internal position, this means that the mid-central [ə]-glide is not articulated, thus creating a monophthongal effect. If we factor in the post-palatal/ non-postpalatal allophonic distribution, the effects reported above become reasonably clear.

In the case of CURE in post-palatal, word-internal contexts, it seems obvious that the "conflict" between a fronted (palatal) articulation such as $\left[\mathrm{j}, \mathfrak{t}, \int, \mathrm{d}, 3\right]$ and the following high-back nucleus of [ซə] has led to regressive assimilation whereby the original high-back nucleus is fronted, while retaining its rounded status. This is clearly shown from the results of Bekker (2009) and, more particularly, the results represented in Figure 3, where the post-palatal CURE vowel clearly moves from a high-front-central position to a mid-central position. It also seems perfectly reasonable to expect the [ə]-in-glide (via progressive assimilation) to become rounded, although this is indeterminable on the basis of the F1/F2 information typically constituting vowel charts, such as those in Figures 2 and 3. On this basis, however, a close phonetic rendering of a word such as Europe would be [jyө.əəp] with a rounded high-centralfront lax vowel replacing [ $\sigma]$ and a rounded mid-central vowel replacing the unrounded [ə] as the glide-target. Undershoot would then lead to realisations which are clearly NURSE-like; in particular, glide-weakening would lead to pronunciations such as [jy(:)ıəp] which is quite NURSE-like in the sense of being high, front, round and (possibly) long (although higher and fronter than the normal SAfE NURSE-value). Another distinct possibility is that, under timepressure, the yod and the nucleus might in effect coalesce (via the spread of lip-rounding to the yod), while there is compensatory lengthening of the now-rounded [ө]-in-glide, i.e. [yө:.əp] which is, for all intents and purposes, virtually equivalent to [чø:.əp]. It should be noted in this regard, that a similar effect is often found with respect to NEAR. Thus, according to Wells (1982:154), the NEAR vowel may sometimes be replaced with the sequence [j3:], especially in non-rhotic accents in Virginia and other parts of the southern USA, as well as western England and Wales. For these accents, a word like year is no longer realised as [jiə], but instead as [j3:]. In fact, Lass (1990) indicates that an analogous realisation is found in SAfE, particularly in words such as year, for which he provides the realisation [jö], although I would imagine that something like [чё] is likely too for obvious assimilatory reasons. During this process, the first element of the diphthong has been absorbed into the glide and the second element is subject to

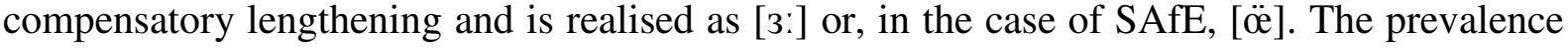
of NURSE-like articulations of the CURE vowel in SAfE, as shown in this article, would seem to point to a similar effect in this regard.

With respect to CURE in non-post-palatal position, the results of this article also seem to indicate the existence of smoothed values, although the evidence is less convincing in this case. Nonetheless, in the case of CURE in non-post-palatal, word-final position, there is evidence for a (non-categorical) preference for fully-diphthongal CURE, while monophthongal, smoothed realisations are more common in word-internal position. One difference between CURE in word-internal, non-post-palatal position and CURE in word-internal, post-palatal position is the prevalence of tokens with a lower F2 in the former as opposed to the latter (see Tables 1, 2 and 
3). Although the F2 values consequently do not overlap with the F2 of NURSE (and certainly not with /u:/ which is even fronter in phonetic space than NURSE), the closest monophthong is still / $\varnothing: /$, thus accounting for the impression of tourist as [t $\varnothing:$ :Iəst]. However, the results for nonpost-palatal CURE in word-internal position are only based on 10 tokens of one word (i.e. tourist), and more research on this particular phenomenon is clearly required.

In terms of speculating on the genesis of these word-internal monophthongal values in nonpost-palatal position, it seems reasonably clear that undershoot would play an important role here too, as well as the assimilatory effect of the preceding consonant. Thus, in the case of more fronted consonants like coronal /t/ (as in tourist), a high-central, relatively monophthongal value appears to be used that is not as fronted as either NURSE or GOOSE, but is closer to the former. In this case, the effect appears therefore to be purely phonetic and due to the assimilatory effect of both the preceding consonant and timing pressures. This analysis is also confirmed by the fact that while CURE in tour is generally diphthongal, it is also clearly more fronted than CURE overall in word-final, non-post-palatal position (cf. Figures 14 and 15). The existence of GOOSE-like values in words containing a presumably fronted consonant (plural, lurid - see Tables 2 and 3) as well as clearly GOOSE-like values in rural and Truro, would indicate that GOOSE-like values have also been phonologised and are (or have been) spreading through the lexicon.

While much explanation for the appearance of monophthongal CURE, particularly in wordinternal position, can be provided by making recourse to purely phonetic facts, it seems clear that the appearance of smoothed values in word-final position complicates matters in this regard; in short, it would appear that monophthongal values are being phonologised and used in contexts which would not necessarily condition them on a purely phonetic basis. Consequently, further fine-tuned acoustic phonetic research, along the lines of, for example, Cho and McQueen (2008), would have to be conducted to determine the degree to which monophthongisation of CURE in SAfE is more than just a phonetic effect. Naturally, the residual effect of Second FORCE Merger [o:]-variants complicates the picture even further.

However, whatever the source of monophthongised CURE variants in SAfE, it is clear that they exist and that, in all likelihood, the prevalence of both NURSE-like and THOUGHT-like variants has been misreported in the available impressionistic literature, with the first being under-reported and the latter being over-reported. In particular, the current results seem to provide reasonably clear evidence for the assertion that, at least with respect to the current sample of subjects, there is not much evidence for an extensive or spreading Second FORCE Merger and that NURSE-like realisations of CURE are quite common, particularly (but not exclusively) in word-internal position in post-palatal context. Indeed, more properly sociolinguistic forms of research would need to be conducted to ascertain the extent to which similar phenomena are attested within the English-speaking community in South Africa as a whole. Specifically, casual observation would seem to suggest that there is a regional effect at play with, for example, Cape Town displaying a greater advance of the Second FORCE Merger than other English-speaking communities in South Africa. There is, of course, also the distinct possibility that the existence of NURSE-like values for CURE has been under-reported in other varieties of English; comparative research (e.g. current SAfE vs. current AusE) would therefore also be useful in this regard. 


\section{References}

Bailey, R. 1984. Notes on South African English. South African Journal of Linguistics 2/3: 145 .

Barnes, J. 2006. Strength and weakness at the interface: Positional neutralization in phonetics and phonology. Berlin and New York: Mouton de Gruyter.

Bekker, I. 2009. The Vowels of South African English. Unpublished PhD dissertation. NorthWest University. Available online: http://dspace.nwu.ac.za/handle/10394/2003 (Accessed 23 January 2014).

Bekker, I. 2012. South African English as a late $19^{\text {th }}$-century extraterritorial variety. English World-Wide 33(2): 127-146.

Bekker, I. 2013. The formation of South African English: A re-evaluation of the role of Johannesburg in the history of South African English. English Today 29(1): 3-9.

Boersma P. and D. Weenink. 2013. Praat: Doing phonetics by computer [software version 5.3.53.] Available online: http://www.praat.org (Accessed 9 July 2013).

Bowerman, S. 2004. White South African English: Phonology. In E.W. Schneider, K. Burridge, B. Kortmann, R. Mesthrie and C. Upton (eds.) A handbook of varieties of English. Berlin: Mouton de Gruyter. pp. 931-942.

Branford W. 1994. English in South Africa. In R. Burchfield (ed.) The Cambridge history of the English language, Vol. V: English in Britain and overseas: Origins and development. Cambridge: Cambridge University Press. pp. 430-496.

Cho, Y. and J. McQueen. 2008. Not all sounds in assimilation environments are perceived equally: Evidence from Korean. Journal of Phonetics 36(2): 239-249.

Cruttenden, A. 2001. Gimson's pronunciation of English. London: Arnold.

Gimson, A.C. (ed.) 1977. Everyman's English pronouncing dictionary. London: J.M. Dent.

Harrington, J., F. Cox and Z. Evans. 1997. An acoustic phonetic study of broad, general and cultivated Australian English vowels. Australian Journal of Linguistics 17(2): 155-184.

Hopwood, D. 1928. South African English pronunciation. Cape Town: Juta.

Lanham, L. 1965. South African English Pronunciation 2065 AD. Taalfasette 1(1): 89-95.

Lanham, L. 1967. The pronunciation of South African English: A phonetic-phonemic introduction. Cape Town: A.A. Balkema.

Lanham, L. and A. Traill. 1962. South African English pronunciation. Johannesburg: Witwatersrand University Press. 
Lass, R. 1990. A 'standard' South African vowel system. In S. Ramsaran (ed.) Studies in the pronunciation of English: A commemorative volume in honour of A.C. Gimson. London and New York: Routledge. pp. 272-285.

Lass, R. 1995. South African English. In R. Mesthrie (ed.) Language and social history: Studies in South African sociolinguistics. Cape Town: David Philip. pp. 89-106.

Lass, R. 2002. South African English. In R. Mesthrie (ed.) Language in South Africa. Cambridge: Cambridge University Press. pp. 104-126.

Lass, R. 2004. South African English. In R. Hickey (ed.) Legacies of colonial English: Studies in transported dialects. Cambridge: Cambridge University Press. pp. 363-386.

Mesthrie, R. 2010. Socio-phonetics and social change: Deracialisation of the GOOSE vowel in South African English. Journal of Sociolinguistics 14(1): 3-33.

Orpen, J. 2008. Concerning the Second FORCE Merger: A comparison of Zimbabwean and South African Englishes. Unpublished undergraduate mini-dissertation. Grahamstown: Rhodes University.

Thomas, E. 2004. Rural southern white accents. In E.W. Schneider, K. Burridge, B. Kortmann, R. Mesthrie and C. Upton (eds.) A handbook of varieties of English: A multimedia reference tool. Berlin: Mouton de Gruyter. pp. 300-324.

Trudgill, P. 2004a. New-dialect formation: The inevitability of colonial Englishes. Edinburgh: Edinburgh University Press.

Trudgill P. 2004b. The dialects of East Anglia: Phonology. In E.W. Schneider, K. Burridge, B. Kortmann, R. Mesthrie and C. Upton (eds.) A handbook of varieties of English: A multimedia reference tool. Berlin: Mouton de Gruyter. pp. 163-177.

Wells J. 1982. Accents of English. Cambridge: Cambridge University Press.

Wells, J. 2008. Longman pronunciation dictionary. Harlow, Essex: Pearson Longman. 


\section{Appendix A1}

Thought

Obscure

Keep

Purse

Brochure

Hyper

Venture

Shirt

Pore

Ice

Europe

Hurt

Course

Assure

Sight

Luxurious

Circus

Fury

Pork

Seat

Shy

Incurable

Caught

Person

Surf

Sheep

Neuron

Spy
Heat

Support

Key

Poor

Certain

Type

Plural

Deport

Teak

Pure

Horse

First

Mural

Repeat

Height

Porter

Speak

Mature

Heap

Curious

Source

Assert

Fighter

Insurance

Hike

Receipt

Thigh

Rehearse 


\section{Appendix A2}

The following reading passage was constructed specifically for use in this research, based loosely on the passage created by Orpen (2008). Words from the CURE lexical set are underlined.

The lecturer had that evil look in his eyes and Jenny could tell that he was about to mention their assignment again. She was sure.

"Don't forget to turn your essays in on time tomorrow," he said before he dismissed the class. He was looking pointedly at Jenny, who with total unconcern kept examining her manicure. She just rolled her eyes. She would have been the first to point out that she didn't exactly have the best track record when it came to deadlines, particularly if they were early in the morning or after a fixture. She was positive that this time would be different though.

It was only later after class that she started feeling somewhat insecure. She caught up with her friends and joined in as they complained loudly.

"I've been trying to do this essay for a week. It's just infuriating." Sarah was saying as they walked out. "I don't even remember half of the stuff we covered on that tour..."

"It's not that bad," said Alex. "The essay only has to be a thousand words. You can remember enough to fill a few pages, surely. I've already finished most of it. I just have to write up a reference list."

“Thanks, Alex - that's reassuring," Sarah said sarcastically.

Jenny sighed. All she could think about was going home to watch The $\underline{\text { Jury }}$. She was starting to get the feeling that procrastinating was an epidemic in the student population. And, sadly, noone had found a cure. 


\section{Appendix B1}

Tour

Source

Thigh

Receipt

Porter

Assert

Plural

Hike

Horse

First

Fighter

Heap

Deport

Certain

Pork

Height

Speak

Lurid

Repeat

Support

Type

Caught

Surf

Shy

Rehearse
Sight

Person

Teak

Course

Key

Rural

Circus

Pore

Heat

$\underline{\text { Poor }}$

Ice

$\underline{\text { Allure }}$

Hurt

Sheep

Shirt

Spoor

Thought

Purse

Seat

Moor

Hyper

Keep

Tourist

Spy 


\section{Appendix B2}

The following reading passage was constructed specifically for use in this research.

Carrie was walking down the corridor with a group of friends, trying to decide how to tackle her report. "I don't remember half the stuff we covered on that tour," she moaned. Sarah giggled and looked pointedly at Sam.

"All I remember is that hike. You know the one - when James had to drag Sam back home with that muck all over his shirt. He decided to go out before everyone else and track some deer, by following their spoor. He ended up at the bottom of a ditch somewhere in a heap. I think when he saw James coming over the hill, it was love at first sight." Everyone laughed, picturing Sam in the rural setting.

“That wasn't the worse part!" said James. "When I eventually tracked Sam down, we found the deer he was stalking. They were an interesting breed. They belonged to a local farmer, but he called them 'sheep.",

"Actually, as I recall, they were some crafty livestock," Sam responded indignantly. "They led me off course... And into a moor. I'm convinced they were planning it the whole time." He looked uncertain.

"I think that was the same day everyone tried to sneak out to the river source," said Carrie, trying to change the subject. "It only took about ten minutes to get caught. And afterwards, Mrs Smith looked so hurt. I still don't think I can use any of this material for my essay, though." She sighed. "I think I'll just head back to Truro. I need to get started soon if I want to hand in my essay first." 